Check for updates

Cite this: RSC Adv., 2018, 8, 22004

\section{Techno-economic analysis of wind power integrated with both compressed air energy storage (CAES) and biomass gasification energy storage (BGES) for power generation}

\author{
Chidiebere Diyoke, ${ }^{a}$ Mathew Aneke, ${ }^{b}$ Meihong Wang ${ }^{b}$ and Chunfei Wu ID *ac
}

A techno-economic analysis of excess wind electricity powered adiabatic compressed air energy storage (A-CAES) and biomass gasification energy storage (BGES) for electricity generation is implemented to determine the performance of the system and the potential profitability of developing such a facility for distributed power generation in the UK by an investor, given the customer's demand for heat and electricity. The customers are considered to be about 1600 households in the Humber region, UK, who use heat generally for space heating and domestic hot water applications. The system is modelled using a developed Matlab computer code and its performance evaluated using total system efficiency (TSE), net present value (NPV) and cost of electricity (COE) as metrics. TSE of $36.8 \%$ is obtained for the system while the COE is found to be about $£ 0.19$ per $\mathrm{kW} \mathrm{h}$. In terms of profitability, the system returned a negative NPV of $£ 2144062$ signalling the non-profitability of the system in the proposed location. However, if $70 \%$ of total investment cost (TIC) of the system is provided for by means of a subsidy, the system becomes economically viable with positive NPV of $£ 132475$ and COE of $£ 0.10$ per $\mathrm{kW} \mathrm{h}$ respectively. The sensitivity study shows that the most significant factors swaying the NPV of the ACAES-BMGES are TIC, O\&M cost, excess wind electricity cost, electricity tariff and cost of diesel fuel.
Received 12th April 2018 Accepted 6th June 2018 DOI: $10.1039 / \mathrm{c} 8 \mathrm{ra03128b}$ rsc.li/rsc-advances generation to renewable based generation. Wind is forecasted to have a good significant future cost reduction potential as its technology improves. ${ }^{4}$

However, wind suffer from a major limitation. It is unpredictable and can only provide energy intermittently. The intermittency leads to a mismatch between electricity demand and supply which consequently introduces an enormous challenge of safety and reliability to the grid operation. In addition, the energy density of wind is low in comparison to that found in conventional fossil fuel sources like coal, oil, gasoline and natural gas. ${ }^{6}$

Energy storage (ES) has been identified as a major solution to the intermittency of wind. This is because of its favourable charging and discharging features, which makes it possible to overcome the fluctuations. ${ }^{7}$ ES has the capacity to even out the mismatch between energy supply and energy demand, thus playing a critical role in energy conservation. It also improves the efficiency and reliability of energy system. The increased efficiency would result to energy conservation and increased cost effectiveness.

Different energy storage (ES) technologies exist: Compressed Air Energy Storage (CAES), Pumped Hydro Storage (PHS), Battery Energy Storage (BES), Super Magnetic Energy Storage (SMES) and Flywheel Energy Storage (FES). ${ }^{1,48-15}$ Though each of the ES technologies offer exclusive advantages, they also suffer
${ }^{a}$ School of Engineering, University of Hull, Hull, UK, HU6 7RX. E-mail: c.wu@hull.ac.uk; Tel: $+44(0) 1482466464$

${ }^{b}$ School of Chemical and Biological Engineering, University of Sheffield, Sheffield, UK, S10 $2 T N$

'School of Energy \& Environmental Engineering, Hebei University of Technology, Tianjin, China 
from special disadvantages. CAES is one of the mature and economically attractive ES technologies with capacity to enable a more efficient and flexible energy system with a better use of the fluctuating wind and other renewable energy sources., ${ }^{3,16}$

In a CAES process, during the charge time at low-cost offpeak periods, ambient air is compressed and stored in large underground caverns or above ground storage vessels using excess electricity. During the discharge time at peak period, the stored compressed air is preheated and expanded through a turbine to produce electricity. ${ }^{17}$

Two basic types of CAES system exist: diabatic CAES (DCAES) and adiabatic CAES (A-CAES). ${ }^{17}$ The D-CAES involves the combustion of fossil fuels with the compressed air (CA) to raise the temperature of the compressed air before expansion via gas turbines, leading to $\mathrm{CO}_{2}$ emissions. The A-CAES stores the heat released during the compression process and reuse it to heat up the stored compressed air in the expansion process. ${ }^{17}$

An alternative CAES system exists called the Isothermal CAES (I-CAES). Isothermal CAES (I-CAES) technology aims to address some of the diabatic and adiabatic CAES, by eradicating the need for fuel and high temperature heat energy storage, thus, offering an enhanced round trip efficiency in the range of 70$80 \% .{ }^{18-20}$ Being an isothermal process, the air is compressed without a change in temperature, thus reducing the work of compression while maximizing the work needed for expansion, through effective heat transfer with surroundings of the air vessel. An experimental study by Alami et al. ${ }^{21}$ on low pressure, modular small scale compressed air energy storage (CAES) system for wind energy storage applications working on the ICAEs principle found that an I-CAES CAES working with a series of off the shelf low pressure cylinders instead of pressurised containers or cavern could be preferable on smallmedium scale (1-10 MW), ${ }^{21}$ and has the following advantages: enables the use cheaper, low pressure storage containers, and practically eliminates the need for heat removal considerations necessary in higher pressure systems to offset the temperature rise after compression. Also, it allows close control of discharge rates according to power consumption needs while maintaining minimal losses. The authors also reported a maximum overall system efficiency of about $97.6 \%$ for the system, while its physical footprint is less than $0.6 \mathrm{~m}^{3}$.

However, while there is substantial research into nearisothermal compression for CAES (by companies like Lightsail and SustainX), ${ }^{22}$ I-CAES is not yet commercially available and any currently available compression that approaches reversible isothermal compression is too slow for industrial use ${ }^{20,23}$ due to the impractically small temperature differences required. ${ }^{20}$ Consequently most reported A-CAES designs opt for a series of adiabatic or poly-tropic compressions, after each of which the compressed air is cooled back to the ambient temperature in order to reduce the both the temperature and volume of the air. ${ }^{22,24}$

There are different options for storing the thermal energy in a CAES process: sensible heat storage (SHS) in liquids and solids, latent heat storage (LHS) in phase change materials (PCMs) and thermochemical heat storage (THS) in chemical reactions. ${ }^{17}$
Although ES can help solve the problem of variability of wind, it does not solve all the problems. Shortfalls resulting from losses in low roundtrip efficiencies of an ES system can be compensated by designing a hybrid ES systems involving the RE source with ES and other energy sources of generation that can be mobilised on short notice and whose generation features must complement each other. ${ }^{25}$ For example, a combination of A-CAES and biomass gasification electrical storage (BMGES) system for meeting the power and heat requirements of a given community. In fact, wind powered A-CAES and BMGES system are complementary to some extent, since some of the heat from syngas produced during gasification can be used by the A-CAES process whereas the biomass gasifier can use some of the cheap heat generated by the compression process of the A-CAES to dry its fuel before gasification. Moreover, combination of A-CAES and BMGES may act as a CHP system, by recovering heat from the dual fuel engine (DFE) during and after the power generation phase. This can only be achieved by placing the ACAES and BMGES close to the area of energy demand, given the technical difficulty to transfer thermal energy at large distances. ${ }^{26}$ Such a plant allows to maximize and conjugate the extensive benefits of distributed generation (DG) ${ }^{11}$ with those of electricity storage.

Many hybrid energy storage systems involving A-CAES has been proposed and analysed in recent years: Garrison and Webber ${ }^{27}$ proposed a novel hybrid configuration involving solar energy and excess wind electricity powered CAES system in which the air from the cavern is preheated by solar energy rather than natural gas prior to expansion in the turbine. They reported an overall efficiency of $46 \%$ for the coupled solar-CAES system. Zhang et al. ${ }^{13}$ analysed a hybrid diesel DG system integrated with A-CAES and thermal energy storage (TES). Their results suggested that the hybrid system's exergy efficiency is $41.5 \%$, and the primary fuel saving ratio is $23.13 \%$. In another study by Singh and Baredar, ${ }^{28}$ a techno-economic assessment of a solar PV, fuel cell, and biomass gasifier hybrid energy system was reported. The cost of electricity (COE) and net present cost of the system was reported to be $0.23 \$$ per $\mathrm{kW} \mathrm{h}$ (15.064 Rs per kW h) and \$79 858.76 (Rs. 5189 003) respectively.

A biomass-fired combined cooling, heating and power system with TES system was studied by Caliano and Bianco. ${ }^{29}$ Their result suggested that the combined use of a TES and cold TES during the hot season could represent a viable economical solution.

In another related study, Singh et al. ${ }^{30}$ carried out optimal sizing and feasibility study of an island micro grid in rural area consisting of PV, wind, biomass and BES system using artificial bee colony $(\mathrm{ABC})$ algorithm. They reported the sizes of the system components as $250 \mathrm{~kW}$ solar PV, $19 \mathrm{~kW}$ wind turbines, 1400 batteries and $40 \mathrm{~kW}$ biomass gasifier. ${ }^{30}$ To verify the strength of the $\mathrm{ABC}$ technique, the results obtained were compared with that obtained from the standard software tool, hybrid optimization model for electric renewable (HOMER) and particle swarm optimization (PSO) algorithm. It was reported that $\mathrm{ABC}$ provides an optimal configuration with least levelised COE of $0.173 \$$ per $\mathrm{kW} \mathrm{h}$. 
A hybrid solar-biomass power plant without ES was studied by Srinivas and Reddy. ${ }^{31}$ Their result indicated that the plant fuel energy efficiency increases from $16 \%$ to $29 \%$ with an increase in solar participation from $10 \%$ to $50 \%$ at the boiler pressure of 20 bar.

To provide a solution for managing excess heat production in tri-generation plant and thus increase the power plant annual efficiency, a hybrid optimization model of biomass trigeneration system combined with TES was studied by Dominković et al. ${ }^{32}$ Three case studies with minimum yearly average power plant efficiencies of $50 \%, 65 \%$ and $75 \%$ respectively were conducted. It was reported that an increase in overall power plant efficiency from $50 \%$ to $65 \%$ in legislation, in order to be eligible for the maximal feed-in tariff, would not affect the economics of the system.

Hence, from the literatures reviewed so far and within the limits of the author's knowledge, no treatment exists in the literature currently that focused on the technical and economic analysis of wind power integrated with both Compressed Air Energy Storage (CAES) and Biomass Gasification Energy Storage (BGES) System for Power generation in the UK. Downdraft gasifier is suited for small and medium-sized applications. ${ }^{33}$ This conversion technology has a fairly efficient biomass to gaseous fuel conversion and produce syngas with relatively low amounts of tar that is suitable for direct use in internal combustion engines. ${ }^{33,34}$ Hence, a fixed bed downdraft gasifier is selected for this work. Given the advantage of A-CAES system and the need to increase RE in the energy mix around the globe, it could be expected that the combination of wind powered ACAES and BMGES hybrid system will be an important trend. Hence, in order to investigate this concept, we developed a mathematical model of A-CAES integrated with BMGES system in Matlab. The A-CAES is powered using off-peak electricity from wind turbine. Technical and economic analysis of the hybrid system is analysed using efficiency, Net Present Value (NPV) and Cost of Electricity (COE) as metrics. The impacts of some technical and economic factors on system efficiency and profitability of the of hybrid system are subsequently investigated.

\section{System description}

The system being proposed is as shown in Fig. 1. It is made of the following components: A-CAES powered by excess wind electricity, Hot air dryer (HAD) for drying biomass; Biomass gasifier (BMG) for generating syngas from dried wood, dual fuel engine (DFE) running on syngas and diesel fuel and heat exchangers (HXs).

First the excess electricity of the wind turbine powers the compression train to compress air to a higher temperature and pressure. The heat of compression of the first stage air compressor

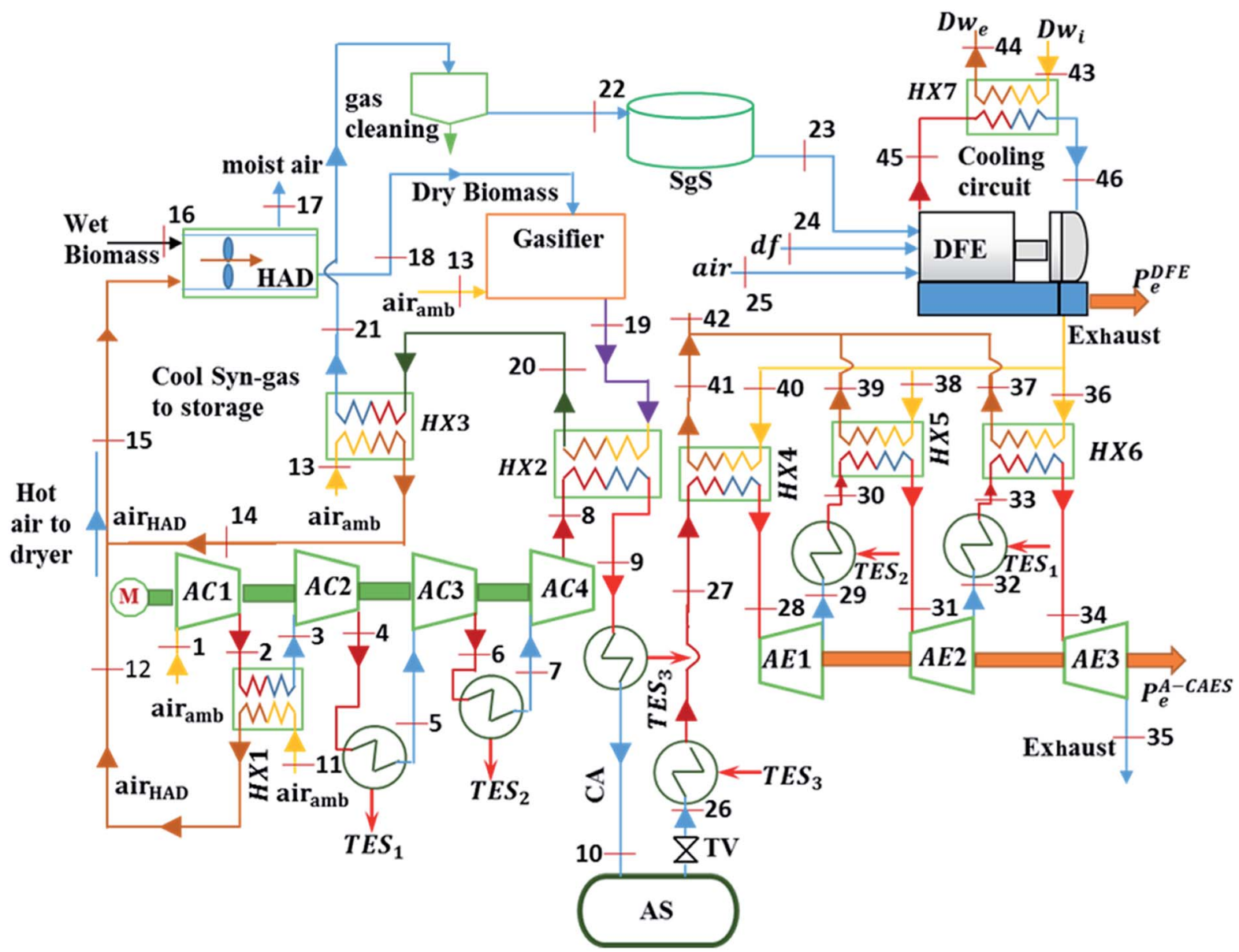

Fig. 1 Schematic diagram of the proposed A-CAES + BMGES system. 
(AC1) is recovered by the air compressor heat exchanger (HX1) for biomass drying in the $\mathrm{HAD}$, while the heat of compression of the remaining three stages (AC2, AC3, AC4) is recovered and stored as $\mathrm{TES}_{1}, \mathrm{TES}_{2}$ and $\mathrm{TES}_{3}$ respectively using the phase changes materials (PCM) in TES tanks, TEST 1 , TEST $_{2}$ and TEST $_{3}$ respectively. The cooled compressed air (CA) is stored in the air store (AS).

Subsequently, wood chips at initial moisture content $\left(\mathrm{MC}_{\mathrm{i}}\right)$ of about $50 \%$ wt. are dried in the HAD to final moisture content $\left(\mathrm{MC}_{\mathrm{f}}\right)$ of about $10 \% \mathrm{wt}$. The dried wood is converted into syngas (sg) in the BMG. The heat carried by the generated syngas in recovered by means of the heat exchanger (HX2) and used to pre heat the temperature of the air exiting the last stage air compressor (AC4). The syngas is further cooled by recovering its heat using a heat exchanger (HX3). The recovered heat is used for biomass drying. Cooling the syngas helps to prevent preignition, to improve the engine volumetric efficiency, and to ease gas clean-up. ${ }^{33}$ Afterwards, the cooled syngas which is limited at a temperature of $60^{\circ} \mathrm{C}$, to minimise condensation, is cleaned and stored in the syngas store (SgS). Syngas from a gasifier contain various contaminants and thus has to undergo several cleaning steps to reduce the concentrations of contaminants to level required by the downstream processes. For use in internal combustion engine, typical syngas cleaning requirements is particulate $\left(<50 \mathrm{mg} \mathrm{m}^{-3}\right)$, tars $\left(<100 \mathrm{mg} \mathrm{m}^{-3}\right) .^{35}$ Therefore, wet syngas cleaning, was used in this study. In such a scheme, the syngas is first passed through a cyclone to reduce particulates. The syngas is then further cooled to a temperature below $100{ }^{\circ} \mathrm{C}$ and passed through a spray scrubber to remove tar and ranges of other contaminants. ${ }^{36}$

When electricity is required, the stored syngas is used to generate electricity in the DFE while the stored cool CA at high pressure exiting the AS is first throttled down to the minimum operating pressure of the AS (40 bar) using a throttle valve (TV) and then heated using $Q_{\mathrm{TES} 3}$. The high temperature pressurised air leaving $Q_{\text {TES3 }}$ is subsequently heated up further by the exhaust heat from the DFE by means of the heat exchangers (HX4), and then expanded in AE1. After expansion in AE1, the temperature of air exiting the first stage $\mathrm{AE}\left(\mathrm{TET}_{\mathrm{AE} 1}\right)$ is heated up first by $Q_{\text {TES2 }}$ and further again by HX5 before it undergoes expansion in AE2. The process of heating and further heating by $Q_{\mathrm{TES}}$ and $\mathrm{HX}$ is repeated until the last stage $\mathrm{AE}$ to produce electricity. Heat is recovered from the cooling water jacket of the DFE using cooling water heat exchanger (HX7).

A techno-economic analysis of the proposed hybrid system has been implemented to determine its value to the utility system and the potential profitability of developing such a facility by an investor, given the customers demand for heat and electricity. The customer is considered to be about 1600 households in the Humber region UK who use heat generally for space heating and domestic hot water applications. For brevity, the proposed hybrid system is hereafter referred to as (A-CAES + BMGES)

\subsection{Demand profiles}

To simulate the proposed system performance for the assumed 1600 households, the electrical and heat demand profiles were generated as shown in Fig. 2. The electrical profile was obtained

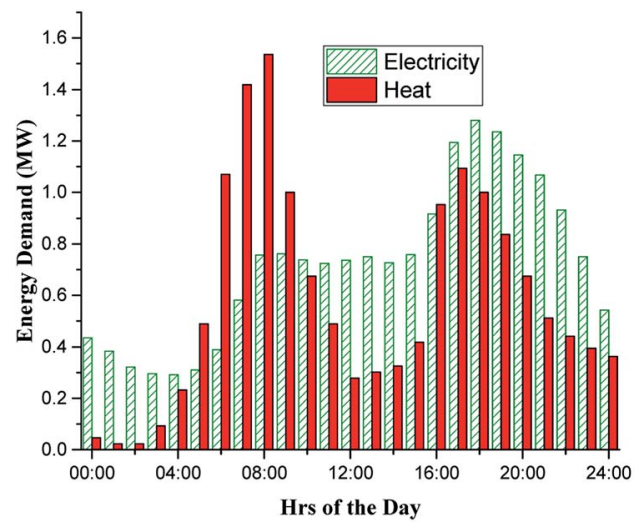

Fig. 2 Daily hourly electrical and thermal demand profiles for North Humberside.

from the data of half-hourly average daily electrical energy consumption in $\mathrm{kW} \mathrm{h}$ for the period $01 / 05 / 2011$ to $31 / 05 / 2012$ for 5554 households from the UK Northern power grid region. ${ }^{37}$ The data was manipulated to give hourly average data based on the average daily electricity consumption of 4115 KW h per household obtained from a DECC report. ${ }^{38}$ The heat demand profiles are based on real hourly average data from a 100 home community housing development in the UK, obtained from a study by Wood. ${ }^{39}$ The data was manipulated to give electricity to heat ratio equal to the national average for UK social housing of $0.28 .^{39}$

\section{Modelling of the A-CAES + BMGES}

The modelling of the proposed system is presented hereunder. To simplify the analysis, the following assumptions is made:

- The system and its sub components in any operating mode attain steady state..$^{24,40}$

- Pressure losses in heat exchangers and pipes is ignored..4,40

- There is no change in enthalpy during the throttling process of CA. ${ }^{24,40}$

- Temperature of the CA in the AS is assumed equal to ambient temperature. ${ }^{24,40}$

- Air and the DFE exhaust gas is treated as ideal gas.

- Space heating water enters $\mathrm{HX} 7$ at $35{ }^{\circ} \mathrm{C}$ and leaves at $55{ }^{\circ} \mathrm{C}^{12}$

- The changes in kinetic and potential energy are neglected.

- Isentropic efficiencies of the compressor and turbine are 0.85 and 0.88 respectively. ${ }^{13}$

- The motor (generator) efficiency of AC (AE) are 0.99 and 0.97 respectively. ${ }^{13}$

- The heat exchangers (HXs) has effectiveness $(\varepsilon)$ of 0.7 .

\subsection{Plant capacity}

The electrical capacity of the proposed system is sized to match the maximum electricity demand of 1300 MW. Any excess/ deficit electricity/heat is sold/bought to/from the grid. The DFE is sized to supply $25 \%$ of the total power while the A-CAES system supplies the rest. 


\subsection{Gasifier and dual fuel engine model}

The design requirement is to generate a rated output $\left(P_{\mathrm{e}, \mathrm{DFE}}\right)$ in the dual fuel mode using syngas mixed with diesel. The performance of the dual-fuelled engine is characterised by a factor called syngas fraction (sf). It indicates the amount of diesel fuel (df) input that is replaced by the syngas (sg) in the dual fuel mode. Diesel replacement up to $80 \%$ is possible. ${ }^{33}$ The thermal power input of the syngas $\left(P_{\mathrm{th}, \mathrm{sg}}\right)$ and diesel $\left(P_{\mathrm{th}, \mathrm{df}}\right)$ to the dual-fuel engine is determined as follows:

$$
\begin{gathered}
P_{\mathrm{th}, \mathrm{sg}}=\frac{P_{\mathrm{e}, \mathrm{DFE}}}{\eta_{\mathrm{O}, \mathrm{DF}}} \times \mathrm{sf} \\
P_{\mathrm{th}, \mathrm{df}}=\frac{P_{\mathrm{e}, \mathrm{DFE}}}{\eta_{\mathrm{O}, \mathrm{DF}}} \times(1-\mathrm{sf})
\end{gathered}
$$

The expected feed rate of biomass on dry basis (d.b) to achieve $P_{\mathrm{th}, \mathrm{sg}}$ is calculated as follows:

$$
\dot{m}_{\mathrm{BG}}(\mathrm{d} . \mathrm{b})=\frac{P_{\mathrm{th}, \mathrm{sg}}}{\mathrm{CGE} \times \mathrm{CV}_{\mathrm{B}}}
$$

\subsection{Dryer}

According to the HAD, as in Fig. 3, the mass balances in the dryer (D) can be written for the dry biomass (B), air (a) and water (w) as follows:

$$
\begin{gathered}
\dot{m}_{\mathrm{B}, \mathrm{D}, \mathrm{i}}=\dot{m}_{\mathrm{B}, \mathrm{D}, \mathrm{e}} \\
\dot{m}_{\mathrm{a}, \mathrm{D}, \mathrm{i}}=\dot{m}_{\mathrm{a}, \mathrm{D}, \mathrm{e}} \\
\dot{m}_{\mathrm{a}, \mathrm{D}}\left(\varphi_{\mathrm{i}}-\varphi_{\mathrm{e}}\right)=\dot{m}_{\mathrm{w}, \mathrm{ev}}=\dot{m}_{\mathrm{w}, \mathrm{i}}-\dot{m}_{\mathrm{w}, \mathrm{e}}
\end{gathered}
$$

where $\dot{m}$ is mass flow rate, $\varphi$ is the humidity ratio and subscripts a, D, B, i, e, w and ev denotes air, dryer, biomass, in, exit/final, water and evaporation for specie involved respectively. The mass flow rate of air entering the HAD $\left(\dot{m}_{\mathrm{a}, \mathrm{D}}\right)$ is obtained as follows:

$$
\dot{m}_{\mathrm{a}, \mathrm{D}}=\dot{m}_{\mathrm{D}, \mathrm{AC}}+\dot{m}_{\mathrm{D}, \mathrm{sg}}
$$

where $\dot{m}_{\mathrm{D}, \mathrm{AC}}$ and $\dot{m}_{\mathrm{D}, \mathrm{sg}}$ denote mass flow rate of air recovered from AC1 and HX3 respectively. The initial feed rate of wt wood chips to the dryer $\left(\dot{m}_{\mathrm{B}, \mathrm{i}}\right)$ at initial moisture content $\left(\mathrm{MC}_{\mathrm{i}}\right)$ on wet

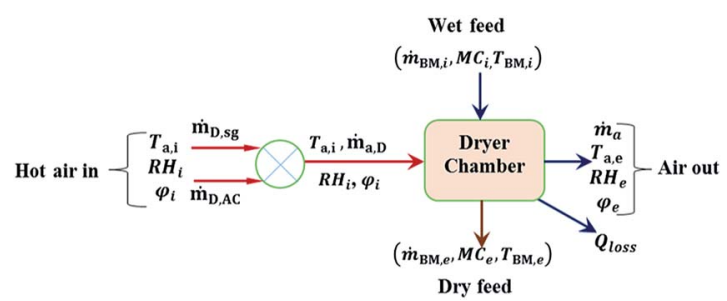

basis is derived from the feed rate of wood in the biomass gasifier $\left(\dot{m}_{\mathrm{BG}}\right)$ as follows:

$$
\dot{m}_{\mathrm{BM}, \mathrm{i}}=\frac{\dot{m}_{\mathrm{BG}}(\mathrm{w} \cdot \mathrm{b})}{\left(1-\mathrm{MC}_{\mathrm{i}} / 1-\mathrm{MC}_{\mathrm{e}}\right)}
$$

The heat required for drying $\left(Q_{\mathrm{D}}\right)$ was obtained from energy balance as follows: $:^{41,42}$

$$
Q_{\mathrm{D}}=Q_{\mathrm{ev}}+Q_{\mathrm{s}}+Q_{1, \mathrm{D}}
$$

$Q_{\mathrm{ev}}$ is the heat required to evaporate water, $Q_{1, \mathrm{D}}$ is heat loss from dryer structures and $Q_{\mathrm{s}}$ is sensible heat required to heat the biomass and drying structure to drying temperature. where:

$$
\begin{gathered}
Q_{\mathrm{ev}}=\dot{m}_{\mathrm{W}, \mathrm{ev}}\left[C_{\mathrm{p}, \mathrm{w}}\left(T_{\mathrm{ev}}-T_{\mathrm{ref}}\right)+C_{\mathrm{p}, \mathrm{wv}}\left(T_{\mathrm{a} 0}-T_{\mathrm{ev}}\right)+L_{\mathrm{wv}}\right] \\
Q_{\mathrm{s}}=Q_{\mathrm{B}, \mathrm{i}}-Q_{\mathrm{B}, \mathrm{e}} \\
Q_{\mathrm{B}, \mathrm{i}}=\left[\dot{m}_{\mathrm{W}, \mathrm{i}} C_{\mathrm{p}, \mathrm{w}}+\dot{m}_{\mathrm{B}, \mathrm{e}} C_{\mathrm{p}, \mathrm{B}}\right]\left(T_{\mathrm{B}, \mathrm{i}}-T_{\mathrm{ref}}\right) \\
Q_{\mathrm{B}, \mathrm{e}}=\left[\dot{m}_{\mathrm{W}, \mathrm{e}} C_{\mathrm{p}, \mathrm{w}}+\dot{m}_{\mathrm{B}, \mathrm{e}} C_{\mathrm{p}, \mathrm{B}}\right]\left(T_{\mathrm{B}, \mathrm{e}}-T_{\mathrm{ref}}\right)
\end{gathered}
$$

Heat loss $\left(Q_{1, \mathrm{D}}\right)$ is expressed as $5 \%$ of the heat input $\left(Q_{\mathrm{D}}\right)$. The heat input to the dryer, $Q_{\mathrm{D}}$ is supplied by the hot air as it is cooled from its initial state $\left(\dot{m}_{\mathrm{a}, \mathrm{D}}, T_{\mathrm{a}, \mathrm{i}}, \mathrm{RH}_{\mathrm{i}}\right)$ to final state $\left(\dot{m}_{\mathrm{a}, \mathrm{D}}\right.$, $T_{\mathrm{a}, \mathrm{e}}, \mathrm{RH}_{\mathrm{e}}$ ). Thus the energy supplied by the hot air (HA) is as follows:

$$
Q_{\mathrm{HA}}=\dot{m}_{\mathrm{a}, \mathrm{D}}\left(h_{\mathrm{a}, \mathrm{i}}-h_{\mathrm{a}, \mathrm{e}}\right)
$$

where

$$
h_{\mathrm{a}}=\left[C_{\mathrm{p}, \mathrm{a}}+\varphi C_{\mathrm{p}, \mathrm{w}}\right]\left(T_{\mathrm{a}}-T_{\mathrm{ref}}\right)
$$

In most hot air dryers, the exit temperature of the dried solid is a few degrees lower than the final temperature of the hot air. ${ }^{43}$ In this model, the difference between $T_{\mathrm{a}, \mathrm{e}}$ and $T_{\mathrm{B}, \mathrm{e}}$ is set to be $5{ }^{\circ} \mathrm{C}$.

With known $\dot{m}_{\mathrm{a}, \mathrm{D}}$ determined from eqn (7), eqn (6) and (9) are solved to obtain the final humidity of air at the exit of the HAD and the temperature of the exiting air and biomass respectively.

The fan electrical power required for circulation of air in the dryer is calculated as follows:

$$
P_{\mathrm{e}, \mathrm{fan}}=\psi \dot{Q}_{\mathrm{air}}
$$

$\psi$ is the specific fan power. In this model $\psi$ is set to $1.5 \mathrm{~kW} \mathrm{~m}{ }^{-3} \mathrm{~s}^{-1}$ as found by Nilsson. ${ }^{44}$

\subsection{Dual fuel engine (DFE) exhaust flow}

From the known fuel input energy, the flow rate of the syngas and diesel fuel is calculated as follows:

$$
\dot{m}(\mathrm{sg}, \mathrm{df})=\frac{P_{\mathrm{th}}(\mathrm{sg}, \mathrm{df}) \times \rho(\mathrm{sg}, \mathrm{df})}{\mathrm{HV}(\mathrm{sg}, \mathrm{df})}
$$

Fig. 3 Hot air dryer system. 
The exhaust gas flow rate of the DFE is estimated using:

$$
\dot{m}_{\mathrm{ex}}=\dot{m}_{\mathrm{df}}+\dot{m}_{\mathrm{sg}}+0.5 N \eta_{\mathrm{v}} V_{\mathrm{s}} \rho_{\mathrm{a}} / 60
$$

Table 1 shows the HAD and DFE input design parameters. The relevant characteristic parameters of the selected diesel engine has been take from the manufacturer's specification. ${ }^{45}$

\subsection{A-CAES system}

3.5.1 Compressor. Assuming maximum work per compressor stage, the mass flow rate of air in each compressor stage $(\dot{m} \mathrm{AC})$ is calculated as follows:

$$
\dot{m}_{\mathrm{a}, \mathrm{AC}}=\frac{P_{\mathrm{wT}} \eta_{\mathrm{m}} \eta_{\mathrm{isen}}}{n_{\mathrm{s}, \mathrm{AC}} C_{\mathrm{p}, \mathrm{air}} T_{\mathrm{amb}}\left(\beta^{\frac{\gamma-1}{\gamma}}-1\right)}
$$

The pressure ratio of each compressor $\left(\beta_{\mathrm{AC}}\right)$ stage is a function of the number of stages $\left(n_{\mathrm{s}, \mathrm{AC}}\right)$ and overall pressure ratio $\left(\beta_{\mathrm{O}, \mathrm{AC}}\right)$ of the compressor. It is calculated using the following equation:

$$
\beta_{\mathrm{AC}}=\beta_{\mathrm{O}, \mathrm{AC}} 1 / n_{\mathrm{s}, \mathrm{AC}}
$$

The outlet temperature from the compressor is obtained using the relation:

$$
T_{\mathrm{AC}}=T_{\mathrm{amb}}\left[1+\left(\frac{\gamma-1}{\beta_{A C}}-1\right) / \eta_{\text {isen, } \mathrm{AC}}\right]
$$

\begin{tabular}{|c|c|c|}
\hline Parameters & Value & Ref \\
\hline \multicolumn{3}{|l|}{ Dryer } \\
\hline Feed rate of wet wood, $\dot{m}_{\mathrm{w}, \mathrm{BM}, \text { in }}\left(\mathrm{kg} \mathrm{h}^{-1}\right)$ & 636.1 & \\
\hline Initial moisture content of feed $\mathrm{MC}_{\mathrm{i}}(\%)$ & 50 & \\
\hline Exit moisture content of feed $\mathrm{MC}_{\mathrm{e}}(\%)$ & 10 & \\
\hline Temperature of the wood feed, $T_{\mathrm{BM}, \mathrm{i}}\left({ }^{\circ} \mathrm{C}\right)$ & 20 & \\
\hline Temperature of the air feed, $T_{\mathrm{a}, \mathrm{i}}\left({ }^{\circ} \mathrm{C}\right)$ & 80 & \\
\hline Humidity of air feed, $\varphi$ (kg per $\mathrm{kg}$ dry air) & 0.006 & \\
\hline Specific heat capacity of dry air, $C_{\mathrm{p}, \mathrm{a}}\left(\mathrm{kJ} \mathrm{kg}^{-1} \mathrm{~K}^{-1}\right)$ & 1.006 & \\
\hline Specific heat of water, $C_{\mathrm{p}, \mathrm{wv}}\left(\mathrm{kJ} \mathrm{kg}^{-1}{ }^{\circ} \mathrm{C}^{-1}\right)$ & 4.186 & \\
\hline Latent heat of water vapour $\mathrm{LH}_{\mathrm{w}, \mathrm{v}}\left(\mathrm{kJ} \mathrm{kg}^{-1}\right)$ & 2256 & \\
\hline Specific heat of dry feed $C_{\mathrm{p}, \mathrm{BM}}\left(\mathrm{kJ} \mathrm{kg}^{-1} \mathrm{~K}^{-1}\right)$ & 1.236 & \\
\hline Specific heat of water vapour, $C_{\mathrm{p}, \mathrm{wv}}\left(\mathrm{kJ} \mathrm{kg}^{-1} \mathrm{~K}^{-1}\right)$ & 2.01 & \\
\hline \multicolumn{3}{|l|}{ DFE } \\
\hline Rated power output, $P_{\mathrm{e}, \mathrm{DFE}}(\mathrm{MW})$ & 0.3 & \\
\hline Exhaust temperature, $T_{\mathrm{ex}}\left({ }^{\circ} \mathrm{C}\right)$ & 461 & 45 \\
\hline Overall efficiency in dual fuel mode $\eta_{\mathrm{O}, \mathrm{DF}}(\%)$ & 20 & 46 \\
\hline Calorific value of syngas, $\mathrm{CV}_{\mathrm{sg}}\left(\mathrm{MJ} \mathrm{m}^{-3}\right)$ & 5.135 & \\
\hline Calorific value of diesel, $\mathrm{CV}_{\mathrm{df}}\left(\mathrm{MJ} \mathrm{kg}^{-1}\right)$ & 45.5 & 47 \\
\hline Engine speed, $N(\mathrm{rpm})$ & 1000 & 45 \\
\hline Engine capacity, $V_{\mathrm{s}}(\mathrm{l})$ & 91.6 & 45 \\
\hline Volumetric efficiency, $\eta_{\mathrm{v}}(\%)$ & 80 & 33 \\
\hline
\end{tabular}

Table 1 Dryer and DFE Design parameters
The heat recovered from AC1 for biomass drying $\left(\mathrm{RH}_{\mathrm{AC} 1}\right)$ was obtained as follows:

$$
\mathrm{RH}_{\mathrm{AC} 1}=\eta_{\mathrm{HX}} \dot{m}_{\mathrm{a}, \mathrm{AC}}\left[h_{\mathrm{e}}-h_{\mathrm{i}}\right]
$$

The mass flow rate of air from AC1 for biomass drying is obtained as follows:

$$
\dot{m}_{\mathrm{D}, \mathrm{AC}}=\frac{\mathrm{RH}_{\mathrm{AC} 1}}{C_{\mathrm{p}, \mathrm{a}}\left(T_{\mathrm{a}, \mathrm{i}}-T_{\mathrm{amb}}\right)}
$$

The syngas (sg) produced from a downdraft BMG is drawn from the high temperature reduction zone operating at about 815-1200 ${ }^{\circ} \mathrm{C}^{48}$ At the point of leaving the gasifier, the temperature of the hot syngas $\left(T_{\mathrm{sg}, \mathrm{i}}\right)$ lies in the range of about 500$816^{\circ} \mathrm{C} \cdot{ }^{\mathbf{4 8 , 4 9}}$ For a given heat exchanger effectiveness $\left(\eta_{\text {recup }}\right)$, the air temperature leaving the Cc HX2 and entering the TEST is obtained as follows:

$$
T_{\mathrm{TEST}, \mathrm{i}}=\frac{\dot{m}_{\mathrm{a}, \mathrm{AC}} C_{\mathrm{p}, \mathrm{a}} T_{\mathrm{AC}}+\eta_{\text {recup }} C_{\text {min }} T_{\mathrm{sg}, \mathrm{i}}}{\dot{m}_{\mathrm{a}, \mathrm{AC}} C_{\mathrm{p}, \mathrm{a}}+\eta_{\text {recup }} C_{\mathrm{min}}}
$$

where $C_{\mathrm{min}}$ is $\min \left[\dot{m}_{\mathrm{a}, \mathrm{AC}} C_{\mathrm{p}, \mathrm{a}}, \dot{m}_{\mathrm{sg}}, C_{\mathrm{p}, \mathrm{sg}}\right]$

The temperature of the syngas leaving the Cc HX $\left(T_{\mathrm{sg}, \mathrm{O}}\right)$ is obtained by energy balance. As the temperature of the air exiting the compressor is somewhat high, all the heat contained in the syngas from the gasifier is not fully recovered. If the temperature of the syngas exiting the $\mathrm{HX} 2$ is more than $200{ }^{\circ} \mathrm{C}$, the heat it contains is recovered further using syngas cooler $\mathrm{HX} 3$ for use in generating hot air at a temperature of about $80^{\circ} \mathrm{C}$ for biomass drying while the syngas is cooled to a final temperature not less than $60{ }^{\circ} \mathrm{C}$

The heat recovered from syngas cooler HX3 for biomass drying $\left(\mathrm{RH}_{\mathrm{D}, \mathrm{sg}}\right)$ was expressed as follows:

$$
\mathrm{RH}_{\mathrm{sg}}=\eta_{\mathrm{HX}} \dot{m}_{\mathrm{a}, \mathrm{sg}}\left[h_{\mathrm{e}}-h_{\mathrm{i}}\right]
$$

The mass flow rate of air from HX3 for biomass drying is obtained as follows:

$$
\dot{m}_{\mathrm{D}, \mathrm{sg}}=\frac{\dot{Q}_{\mathrm{sg}, \mathrm{D}}}{C_{\mathrm{p}, \mathrm{a}}\left(T_{\mathrm{a}, \mathrm{i}}-T_{\mathrm{amb}}\right)}
$$

3.5.2 Thermal energy storage tank (TEST). The thermal storage capacity of the TEST is expressed as follows:

$$
Q_{\mathrm{TES}}=\dot{m}_{\mathrm{a}, \mathrm{AC}} C_{\mathrm{P}, \mathrm{air}} \eta_{\mathrm{TES}}\left[T_{\mathrm{TEST}, \mathrm{i}}-T_{\mathrm{PCM}, \mathrm{c},}\right]
$$

PCM thermal storage media has been considered in the present analysis because among the various heat storage techniques, latent heat (LH) TES has the capacity to provide large heat storage capacity and isothermal behaviour during the charging and discharging processes. The other benefits of LH TES include compactness in sizes and low weight per unit storage capacity. ${ }^{50}$ To achieve a suitable TES, the highest melting point of the PCM in each TEST must match the required turbine inlet temperature for each stage $\left(\mathrm{TIT}_{\mathrm{sn}}\right)$. The chosen melting point of PCM $\left(T_{\mathrm{m}}\right)$ in each TEST is related to the entering temperature of the air $\left(T_{\mathrm{TEST}, \mathrm{in}}\right)$ 
according to the relation $T_{\mathrm{m}}=T_{\mathrm{TEST}, \mathrm{i}}-10{ }^{\circ} \mathrm{C}$. during the discharge mode, the temperature of the PCM when cold $\left(T_{\mathrm{PCM}, \mathrm{c}}\right)$ must always be above the temperature of the cold pressurised air entering the TEST. In the model, $T_{\mathrm{PCM}, \mathrm{c}}$ is set as $50{ }^{\circ} \mathrm{C}, 70{ }^{\circ} \mathrm{C}$ and $50{ }^{\circ} \mathrm{C}$ for $\mathrm{TEST}_{1}, \mathrm{TEST}_{2}$ and $\mathrm{TEST}_{3}$ respectively. Table 2 shows the thermo physical properties and cost of the PCMs.

The mass $(m)$ of the PCM in each TEST is estimated as follows: ${ }^{51}$

$$
m=\frac{Q_{\mathrm{TES}}}{\left[C_{\mathrm{p}, \mathrm{sol}}\left(T_{\mathrm{m}}-T_{\mathrm{PCM}, \mathrm{c}}\right)+\Delta L_{\mathrm{m}}+C_{\mathrm{p}, \mathrm{liq}}\left(T_{\mathrm{TEST}, \mathrm{i}}-T_{\mathrm{m}}\right)\right]}
$$

where subscript $m$ stands melting, sol for solid and liq for liquid. The magnitude of the recovered energy depends on the roundtrip efficiency (RTE) of the charge/discharge cycles. The outlet temperature of the air from the TEST $\left(T_{\text {TEST,O }}\right)$ is calculated thus:

$$
T_{\mathrm{TEST}, \mathrm{e}}=\mathrm{RTE} \times \frac{Q_{\mathrm{TES}}}{\dot{m}_{\mathrm{a}, \mathrm{AE}}}+T_{\mathrm{bed}, \mathrm{i}}
$$

The temperature of the air leaving HX4, HX5 and HX6 and entering the AE1, AE2 and AE3 respectively (TIT) in each stage is obtained by energy balance as follows:

$$
\mathrm{TIT}_{\mathrm{AE}}=T_{\mathrm{TEST}, \mathrm{e}}+\dot{m}_{\mathrm{ex}} C_{\mathrm{P}, \mathrm{ex}}\left(T_{\mathrm{ex}, \mathrm{in}}-T_{\mathrm{ex}, \mathrm{O}}\right) / \dot{m}_{\mathrm{AE}} C_{\mathrm{P}, \text { air }}
$$

The outlet temperature of the DFE exhaust gas $\left(T_{\mathrm{ex}, \mathrm{O}}\right)$ is set to the stack temperature of the selected dual fuel engine which is $120{ }^{\circ} \mathrm{C}$ to prevent the corrosive effects of condensation in the exhaust piping. ${ }^{52}$

3.5.3 Air store volume. The output power of the A-CAES system depends on the volume of air compressed during charging. The volume of the storage chamber $\left(V_{\mathrm{AS}}\right)$ is estimated as follows:

$$
V_{\mathrm{AS}}=\frac{\dot{m}_{\mathrm{a}, \mathrm{AC}} t_{\mathrm{ch}} R_{\mathrm{a}} T_{\mathrm{a}, \mathrm{AS}}}{\left(P_{\max }-P_{\mathrm{min}}\right)}
$$

3.5.4 Air expander (AE). The outlet temperature of air exiting the $\mathrm{AE}$ in each stage $T_{\mathrm{AE}, \mathrm{o}}$ is calculated as follows:

$$
T_{\mathrm{AE}, \mathrm{e}}=T_{\mathrm{AE}, \mathrm{i}}\left[1-\eta_{\text {isen,AE }}\left(1-\beta_{\mathrm{AE}} \frac{-\gamma+1}{\gamma}\right)\right]
$$

The charge and discharge time ratio the $\mathrm{AC}$ to the $\mathrm{AE}$ is directly dependent on the discharge to charge mass ratio and its density and can be represented as: ${ }^{53}$

$$
\frac{t_{\mathrm{ch}}}{t_{\mathrm{dch}}}=\dot{m}_{\mathrm{ch}} / \dot{m}_{\mathrm{dch}}
$$

The generated power output by the A-CAES $\left(P_{\mathrm{AE}}\right)$ and the total power output by the hybrid system $\left(P_{\mathrm{T}}\right)$ at a given instant is calculated by the following equations:

$$
\begin{gathered}
P_{\mathrm{AE}}=\sum_{\mathrm{i}}^{n_{\mathrm{s}, \mathrm{AE}}} n_{\mathrm{s}, \mathrm{AE}} \times \dot{m}_{\mathrm{a}, \mathrm{AC}} C_{\mathrm{P}, \mathrm{a}}\left(T_{\mathrm{AE}, \mathrm{i}}-T_{\mathrm{AE}, \mathrm{e}}\right) \\
P_{\mathrm{T}}=P_{\mathrm{AE}}+P_{\mathrm{e}, \mathrm{DFE}}
\end{gathered}
$$

3.5.5 Waste heat recovery (WH) for district heating (DH). In the present analysis, the supply of medium low pressure hot water at a network supply temperature of $55^{\circ} \mathrm{C}$ for domestic hot water or district heating $(\mathrm{DH}) /$ low grade heat process requirements ${ }^{55,56}$ is considered. Due to the low temperatures, Counter current (Cc) shell-and-tube type heat exchangers with high efficiency and low operating temperature difference is considered. ${ }^{57}$ Heat can be recovered from three sources in the system (if available). These are the $\mathrm{AE}$ exhaust, the cooling water jacket and the hot exhaust gas. ${ }^{58,59}$ In typical engines, $30 \%$ of the fuel energy input is contained in the jacket water and is capable of producing 90 to $99{ }^{\circ} \mathrm{C}$ hot water. ${ }^{52}$

Based on the thermodynamic analysis using energy balances, the following equations can be used to estimate the recovered thermal energy from the cooling water jacket. The heat content of the cooling water is estimated based on the assumption that $30 \%$ of the fuel input is lost in the cooling water. ${ }^{52}$

$$
\mathrm{RH}_{\mathrm{cw}}=0.3 \eta_{\mathrm{HX}}\left(P_{\mathrm{th}, \mathrm{sg}}+P_{\mathrm{th}, \mathrm{df}}\right)
$$

Counter current flow configuration is considered for all HXs and the area of all heat exchangers is modelled using LMTD method. ${ }^{60}$ The energy balance equations applied in the HX is as follows:

$$
\mathrm{RH}_{\mathrm{cw}}=\dot{m}_{\mathrm{c}}\left[h_{\mathrm{c}, \mathrm{e},}-h_{\mathrm{c}, \mathrm{i}}\right]=\dot{m}_{\mathrm{h}}\left[h_{\mathrm{h}, \mathrm{i}}-h_{\mathrm{h}, \mathrm{e}}\right]
$$

where the subscript $\mathrm{c}$ and $\mathrm{h}$ denote cold and hot respectively. The heat transfer area of the HX is obtained as follows:

$$
A_{\mathrm{HX}}=\frac{\mathrm{RH}_{\mathrm{cw}}}{U \Delta T_{\mathrm{m}}}
$$

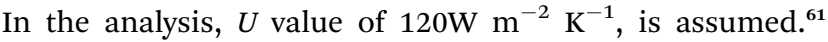
Similar procedure is followed for the calculation of the area of other HXs.

Table 2 Thermo physical properties of the PCMs. ${ }^{54}$

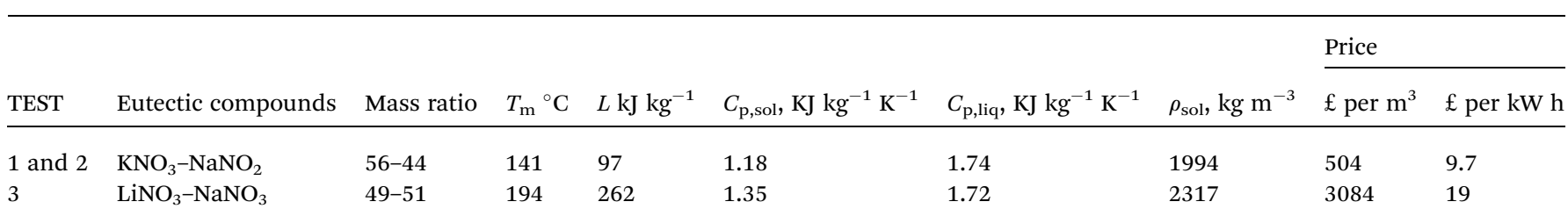




\subsection{System performance criteria}

3.6.1 Energy efficiency. The system energy efficiency is analysed with two parameters: the system electrical efficiency (SEE) and the total system efficiency (TSE). SEE is the ratio of the useful net energy output from the system to the total energy input. TSE is the ratio of the sum of the net useful electric output and net useful recovered heat from system, to the total fuel energy input. ${ }^{\mathbf{4 0 , 5 3 , 6 2}}$

$$
\begin{gathered}
\mathrm{SEE}=P_{\mathrm{T}} t_{\mathrm{dch}} /\left(P_{\mathrm{WT}}+E_{\mathrm{fuel}}\right) t_{\mathrm{ch}} \\
\mathrm{TSE}=\left(P_{\mathrm{T}}+\mathrm{RH}_{\mathrm{cw}}\right) t_{\mathrm{dch}} /\left(P_{\mathrm{WT}}+E_{\mathrm{fuel}}\right) t_{\mathrm{ch}}
\end{gathered}
$$

where $E_{\text {fuel }}$ is the total fuel input consisting of biomass energy input and diesel fuel energy inputs to the DFE system

The term useful output (for both electricity and heat) covers all the electricity or heat produced, no matter what the demand in the study area is. Table 3 shows the values for the input parameters used in the A-CAES model.

\subsection{Equipment cost estimation}

The hybrid system ids made up of different components $(x)$. The total investment cost of component $(x)$ is made up two cost factors: ${ }^{64}$

- Final installed cost or direct capital cost $\left(c_{x}\right)$ : the purchased equipment costs $\left(c_{x}\right)$ and other costs $\left(c_{\mathrm{o}}\right)$ associated with equipment installation, piping, instrumentation, controls, electrical equipment.

- Indirect costs $\left(c_{x}^{\mathrm{i}}\right)$ : cost of materials, land, civil structural and architectural work, and service facilities.

The total capital cost $\left(c_{x}^{\mathrm{T}}\right)$ is the sum of the final installed cost $c_{x}$ and indirect costs $\left(c_{x}^{\mathrm{i}}\right)$ i.e. $\mathrm{c}_{x}^{\mathrm{T}}=c_{x}+c_{\mathrm{o}}+c_{x}^{\mathrm{i}}$.

The cost equation used in the model for the calculation of purchased equipment cost for HXs, AE and AC in (£) is as follows:

$$
\begin{gathered}
c_{\mathrm{HX}}=\left(2800+54 A_{\mathrm{HX}}^{1.2}\right) \times \mathrm{cf}_{\$-£} \times(1+e)^{\mathrm{BY}-\mathrm{CY}}(\text { ref. 66) } \\
c_{\mathrm{AC}}=\left(400 \times \mathrm{cf}_{\$-£}\right) \times(1+e)^{\mathrm{BY}-\mathrm{CY}}(\text { ref. 66) } \\
c_{\mathrm{AE}}=\left(400 \times \mathrm{cf}_{\$-£}\right) \times(1+e)^{\mathrm{BY}-\mathrm{CY}}(\text { ref. 66) }
\end{gathered}
$$

Table 3 Input parameters used in the CAES model

\begin{tabular}{ll}
\hline Parameter, symbol (unit) & Value \\
\hline Ambient temperature, $T_{\mathrm{amb}}\left({ }^{\circ} \mathrm{C}\right)$ & 25 \\
Ambient pressure, $p_{\mathrm{amb}}(\mathrm{bar})$ & 1.0132 \\
Rated power of compression train, $P_{\mathrm{AC}}(\mathrm{MW})$ & 1 \\
Compressor overall pressure ratio, $P_{\mathrm{r}, \mathrm{AC}}$ & 70 \\
Ratio of specific heats, $\gamma$ & 1.4 \\
Gas constant, $R\left(\mathrm{~kJ} \mathrm{~kg}^{-1} \mathrm{~K}^{-1}\right)$ & 287 \\
Round trip efficiency of TEST, $\eta_{\mathrm{RTE}}$ & 0.7 \\
Air store min/max pressure, $P_{\mathrm{min}}(\mathrm{bar})$ & $40 / 70$ \\
Charge-discharge mass flow ratio & $4 / 3$ \\
Inlet pressure of AE1, $P_{\mathrm{AE} 1}(\mathrm{bar})$ & 40 \\
Expander overall pressure ratio, $P_{\mathrm{r}, \mathrm{AE}}$ & 40
\end{tabular}

Ref.

.

.

63
To evaluate the proposed integrated system economic performance, the cost of electricity (COE), total life cycle cost (TLCC) and net present value (NPV) were computed. The COE is the minimum price at which energy must be sold for an energy project to break even.

where is $\mathrm{cf}_{\$-£}$ conversion factor for dollar to pounds; BY is base year and CY is currency year.

The capital cost of the TEST including the AS is made up of the capital cost of the steel tanks, the PCM filling it and insulation as follows: ${ }^{67}$

$$
\begin{aligned}
c_{\mathrm{TEST}}= & \left(V_{\text {steel-TEST }}+V_{\text {steel-AS }}\right) \rho_{\text {steel }} \\
& \times c_{\text {steel }}+M_{\mathrm{PCM}} \times c_{\mathrm{PCM}}+A_{\text {insu }} \times c_{\text {insu }}
\end{aligned}
$$

In the model, an insulation thickness of $0.038 \mathrm{~m}$ and density of steel of $7900 \mathrm{~kg} \mathrm{~m}^{-3}$ is used. ${ }^{67}$ The cost of stainless steel $\left(c_{\text {steel }}\right)$ is obtained as $3.18 £$ per $\mathrm{kg}$ from. ${ }^{68}$ The capital cost of the A-CAES assembly is estimated with the following equation:

$$
c_{\mathrm{CAES}}=c_{\mathrm{AC}}+c_{\mathrm{TEST}}+c_{\mathrm{AE}}
$$

The specific capital cost of biomass gasifier coupled to an internal combustion engine electric generator set (BMG + EGS) for power generation and CHP was quoted by IEA ${ }^{69}$ to lie in the range of 3000 to 4000 ( $\$$ per $\mathrm{kW}_{\mathrm{e}}$ ) in year 2007. Because of technology learning, the lower value of $3000 \mathrm{~S}$ per $\mathrm{kW}_{\mathrm{e}}$ is used in the analysis and increased by $5 \%$ for contingencies and BOP.

The purchase equipment cost of the hot air dryer (HAD), cyclone and scrubber was obtained by scaling using the "sixtenths rule". ${ }^{65}$ In this approach, the costs $\left(c_{\mathrm{G}}\right)$ of a given plant size $\left(\dot{m}_{\mathrm{G}}\right)$ is obtained from a known or reference plant size $\left(\dot{m}_{\text {ref }}\right)$ and cost $\left(c_{\text {ref }}\right)$ using the following equation: ${ }^{65}$

$$
c_{G}=\operatorname{cf}_{\$-£} \times\left(\frac{\dot{m}_{\mathrm{G}}}{\dot{m}_{\mathrm{ref}}}\right)^{\varphi} \times c_{\mathrm{ref}} \times(1+e)^{\mathrm{BY}-\mathrm{CY}}
$$

where $\varphi$ is a scaling factor.

Table 4 shows the reference cost factors used in the computation. An average $\varphi$ value of 0.6 has been used in the analysis. ${ }^{65}$ Finally, cost of the hot water tank $\left(c_{\mathrm{HWT}}\right)$ vary widely depending on its volume, quality and its capabilities. In the model, a modest low cost value of $925\left(£\right.$ per $\left.\mathrm{m}^{3}\right)$ has been used. ${ }^{70}$

Cost escalation factor $(e)$ also called inflation rate, is used to account for the increase in cost of components and services over time. Naturally, these cost parameters are all subjected to strong uncertainties; therefore, in the present study all item costs were escalated from their base year to 2017 using only one inflation rate $e$.

\subsection{Economic analysis of the integrated system}

Table 4 Reference costs of equipment with their maximum size

\begin{tabular}{lllll}
\hline Unit & Base capacity & Base cost $(\$)$ & CY & Ref. \\
\hline HAD & $500 \mathrm{~kg} \mathrm{~h}^{-1}$ & 19891 & 2010 & 43 \\
Cyclone & $9 \mathrm{~m}^{3}$ gas per s & $1.36 \times 10^{6}$ & 2002 & 36 \\
Scrubber & $9 \mathrm{~m}^{3}$ gas per s & $4.56 \times 10^{6}$ & 2002 & 36
\end{tabular}


First an estimate of the TLCC for the system is carried out as follows: ${ }^{71}$.

$$
\begin{aligned}
\mathrm{TLCC}= & {\left[\mathrm{TIC}-\mathrm{Tax} \times\left(c_{\mathrm{D}}\right)_{\mathrm{PV}}+(1-\mathrm{Tax}) \times\left\{\left(c_{\mathrm{O} \& \mathrm{M}}\right)_{\mathrm{PV}}\right.\right.} \\
& \left.\left.+\left(c_{\mathrm{En}}\right)_{\mathrm{PV}}\right\}\right]
\end{aligned}
$$

The total investment cost of the integrate system is the sum of the total capital cost $\left(c_{x}^{\mathrm{T}}\right)$ of the various components that make up the system as follows:

$$
\mathrm{TIC}=\sum_{\mathrm{i}} c_{x}+c_{\mathrm{o}}+c_{x}^{\mathrm{i}}
$$

The remaining direct costs $\left(c_{\mathrm{o}}\right)$ and indirect costs $\left(c_{x}^{\mathrm{i}}\right)$ are related with equipment installation, piping, instrumentation, controls, electrical equipment and materials, land, civil structural and architectural work, and service facilities. These costs cannot be estimated directly. In the model, they are calculated as $5 \%$ of the purchased equipment costs i.e. $\left(c_{0}+c_{x}^{\mathrm{i}}=0.5_{x}\right)$

The annual operation and maintenance (O\&M) cost can be expressed as a percentage of the capital cost. ${ }^{\mathbf{4} 11}$ In the model, the O\&M cost is estimated as $5 \%$ of the TIC. ${ }^{4}$ The annual cost of the input energy $\left(c_{\mathrm{En}, \mathrm{i}}\right)$ i.e. the cost of biomass $\left(c_{\mathrm{w}, \mathrm{BM}}\right)$, diesel $\left(c_{\mathrm{df}}\right)$ and excess wind energy $\left(P_{\mathrm{WT}}\right)$ cost $\left(c_{\mathrm{r}, \mathrm{e}}\right)$ used by the integrated system is estimated as follows:

$$
\begin{gathered}
c_{\mathrm{En}, \mathrm{i}}=\mathrm{hrs}_{\mathrm{yr}} \times\left\{\left(\dot{Q}_{\mathrm{df}} \times c_{\mathrm{df}}+\dot{m}_{\mathrm{BM}} \times c_{\mathrm{W}, \mathrm{BM}}\right)+P_{\mathrm{WT}} \times c_{\mathrm{r}, \mathrm{e}}\right\} \\
c_{\mathrm{W}, \mathrm{BM}}=-0.0129 \mathrm{MC}^{2}-0.0673 \mathrm{MC}+83.925
\end{gathered}
$$

The cost of wet biomass feed $\left(c_{\mathrm{w}, \mathrm{BM}}\right)$ at any moisture content (MC) for industry is estimated as follows:

Data for fitting $c_{\mathrm{w}, \mathrm{BM}}$ above has been taken from the report AEBIOM-wood fuels handbook. ${ }^{72}$ Finally the COE is calculated as follows: ${ }^{71}$.

$$
\mathrm{COE}=\frac{\mathrm{TLCC}}{\mathrm{AEO}} \times \mathrm{UCRF}
$$

The ultimate capital recovery factor (UCRF) is calculated using.

$$
\mathrm{UCRF}=\frac{d_{\mathrm{r}}\left(1+d_{\mathrm{r}}\right)^{n}}{\left(1+d_{\mathrm{r}}\right)^{n}-1}
$$

The real discount $\left(d_{\mathrm{r}}\right)$ rate is calculated from the nominal discount rate $(r)$ using the following formula: ${ }^{71}$.

$$
d_{\mathrm{r}}=[(1+r) /(1+e)]-1
$$

In the constant dollar analysis, it is necessary to convert cash flows for depreciation from current to constant dollars using the inflation rate $(e)$. The following expression shows the conversion from current depreciation $(D)$ to constant depreciation $\left(D_{\mathrm{r}}\right)$ :

$$
D_{\mathrm{r}}(n)=D(n) \times(1-e)^{n}
$$

The present value (PV) of the O\&M, energy cost $\left(c_{\mathrm{En}}\right)$ and depreciation $\left(c_{\mathrm{D}}\right)$ is obtained by multiplying the appropriate energy cost, with the present value factor as follows.

$$
\mathrm{PV}(\mathrm{i})=\sum_{n=1}^{n} \frac{\mathrm{i}_{n}}{\left(1+d_{\mathrm{r}}\right)^{n}} \quad \mathrm{i}=\left\{c_{\mathrm{O} \& \mathrm{M}}, c_{\mathrm{D}}, c_{\mathrm{En}}\right\}
$$

The net present value (NPV) which represents the present value of all the expenses and revenues streams over the life of the system is evaluated with the following: ${ }^{11,71}$

$$
\begin{aligned}
\mathrm{NPV}= & -\mathrm{TIC} \\
& +\sum_{1}^{n} \frac{(1-\mathrm{Tax}) \times\left(R-c_{\mathrm{O} \& \mathrm{M}}-c_{\mathrm{En}, \mathrm{i}}\right)+\operatorname{Tax} \times\left(D_{\mathrm{d}}\right)}{\left(1+d_{\mathrm{r}}\right)^{n}}
\end{aligned}
$$

where $R$ is the revenue generated by selling electricity and heat produced by the system. $R$ is estimated as follows:

$$
\begin{gathered}
R=R_{\mathrm{e}}+R_{\mathrm{h}} \\
R_{\mathrm{e}}=\operatorname{Days}_{\mathrm{yr}} \times\left[\sum_{1}^{t_{\mathrm{dch}}} \mathrm{ed}_{\mathrm{hr}} \times c_{\mathrm{ect}}+\sum_{1}^{t_{\mathrm{dch}}} \mathrm{ee}_{\mathrm{hr}} \times c_{\mathrm{est}}-\sum_{1}^{t_{\mathrm{dch}}} \mathrm{de}_{\mathrm{hr}} \times c_{\mathrm{ebt}}\right]
\end{gathered}
$$

$$
R_{\mathrm{h}}=\operatorname{Days}_{\mathrm{yr}} \times\left[\sum_{1}^{t_{\mathrm{dch}}} \mathrm{hd}_{\mathrm{hr}} \times h_{\mathrm{hct}}+\sum_{1}^{t_{\mathrm{dch}}} \mathrm{eh}_{\mathrm{hr}} \times c_{\mathrm{hst}}-\sum_{1}^{t_{\mathrm{dch}}} \mathrm{dh}_{\mathrm{hr}} \times c_{\mathrm{hbt}}\right]
$$

\begin{tabular}{|c|c|c|}
\hline Parameter, symbol (unit) & Value & Ref. \\
\hline Diesel fuel cost, $c_{\mathrm{df}}\left(\$\right.$ litre $\left.^{-1}\right)$ & 1.15 & 76 \\
\hline Inflation rate, $e(\%)$ & 3 & \\
\hline Rejected wind electricity cost, $c_{\mathrm{r}, \mathrm{e}}(£$ per $\mathrm{kW} \mathrm{h})$ & 0.042 & \\
\hline Electricity consumer tariff, $c_{\text {ect }}(£$ per $\mathrm{kW} \mathrm{h})$ & 0.14 & \\
\hline Electricity sell to grid tariff, $c_{\text {est }}(£$ per $\mathrm{kW} \mathrm{h})$ & 0.042 & \\
\hline Electricity buy back tariff, $c_{\text {ebt }}(\$ £)$ & 0.042 & \\
\hline Heat consumer tariff, $c_{\mathrm{hct}}(£$ per $\mathrm{kW} \mathrm{h})$ & 0.10 & 77 \\
\hline Heat sell back tariff, $c_{\mathrm{hst}}(£$ per $\mathrm{kW}$ h) & 0.10 & 77 \\
\hline Heat buy back tariff, $c_{\mathrm{hbt}}(£)$ & 0.10 & 77 \\
\hline Cost of diesel fuel, $c_{\mathrm{df}}(£$ per litre $)$ & 1.15 & 76 \\
\hline Insulation cost, $c_{\text {ins }}\left(\$ \mathrm{~m}^{-2}\right)$ & 235 & 68 \\
\hline Nominal discount rate, $d(\%)$ & 10 & 4 \\
\hline Charging time (discharging time) $(\mathrm{h})$ & $8(6)$ & \\
\hline Annual operating days & 310 & \\
\hline Economic life, $n$ yrs & 20 & \\
\hline Tax rate, $T(\%)$ & 34 & 71 \\
\hline
\end{tabular}

In the model, the excess wind electricity price $\left(c_{\mathrm{r}, \mathrm{e}}\right)$ while charging is assumed to be $42 £$ MW per h, the 2017 average offpeak spot price. $^{73}$ For discharging (selling), the electricity consumer tariff/price $\left(c_{\text {ect }}\right)$ is assumed to be $14.05 \mathrm{p}$ per $\mathrm{kW} \mathrm{h}$, the UK national average price per $\mathrm{kW} h$ for electricity. ${ }^{74}$ The electricity buy back tariff $\left(c_{\text {ebt }}\right)$ and the electricity sell back tariff $\left(c_{\text {est }}\right)$ is assumed as $43 £$ MW per h, the average 2017 wholesale electricity price in the UK. ${ }^{75}$ Table 5 shows the representative values for the main cost parameters of the integrated system. All results have been reported in the 2017 constant dollar year. The methodology described in the preceding section is applied to

Table 5 Main cost parameters of the integrated system 
analyse the performance of the system. Fig. 4 shows a physical set up of the algorithm for the implementation of the model in Matlab.

\section{Results and discussion}

Table 6 lists the values of pressure (bar) temperature (K) and mass flow rate $\left(\mathrm{kg} \mathrm{s}^{-1}\right)$, determined for the each stream of the system. Using the table data and the equations developed in the preceding section, performance parameters for the system has been calculated. Under design conditions, the HAD is capable of producing $318.03 \mathrm{~kg}$ of dry wood per hour with an efficiency of about $53.8 \%$ from an initial wet wood feed rate of $636.05 \mathrm{~kg}$ per hour. To achieve this, the HAD uses $190.8 \mathrm{~kW}$ of thermal energy supplied from recovered thermal energy from $\mathrm{AC}_{1}$ $(173.25 \mathrm{~kW})$ and syngas $(61.98 \mathrm{~kW})$. At $80 \%$ syngas fraction (sf), the overall diesel and syngas consumption to deliver an electric output of $300 \mathrm{~kW}_{\mathrm{e}}$ in dual fuel mode is estimated as 23.74 and $885.24 \mathrm{~kg} \mathrm{~h}^{-1}$ respectively. This corresponds to a biomass and air feed flow rate of 318.03 and $617.65 \mathrm{~kg} \mathrm{~h}^{-1}$ respectively in the

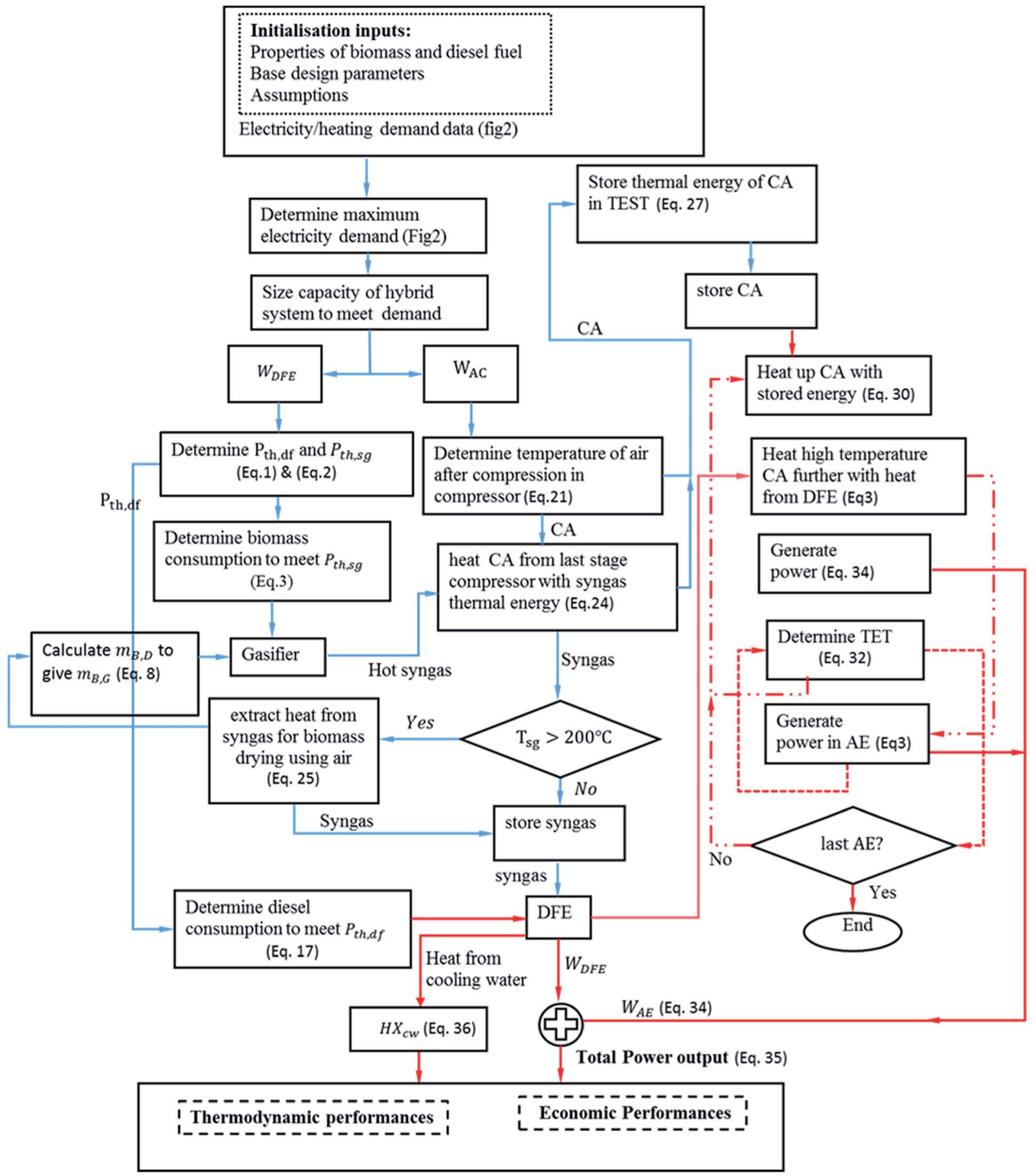

Fig. 4 Computational algorithm for the implementation of the model in Matlab. 
Table 6 Stream properties of the system

\begin{tabular}{|c|c|c|c|c|c|c|c|}
\hline No. & $T(\mathrm{~K})$ & $P$ (bar) & $\begin{array}{l}\dot{m} \\
\left(\mathrm{~kg} \mathrm{~s}^{-1}\right)\end{array}$ & No. & $T(\mathrm{~K})$ & $P$ (bar) & $\begin{array}{l}\dot{m} \\
\left(\mathrm{~kg} \mathrm{~s}{ }^{-1}\right)\end{array}$ \\
\hline 1 & 298.0 & 1.01 & 1.98 & 24 & 298.0 & 1.01 & 0.01 \\
\hline 2 & 422.3 & 2.93 & 1.98 & 25 & 298.0 & 1.01 & 0.74 \\
\hline 3 & 298.0 & 1.01 & 1.98 & 26 & 303.1 & 40.0 & 1.98 \\
\hline 4 & 422.3 & 8.48 & 1.98 & 27 & 403.1 & 40.0 & 2.64 \\
\hline 5 & 298.0 & 1.01 & 1.98 & 28 & 443.1 & 40.0 & 2.64 \\
\hline 6 & 422.3 & 24.5 & 1.98 & 29 & 327.6 & 11.7 & 2.64 \\
\hline 7 & 298.0 & 1.01 & 1.98 & 30 & 383.2 & 11.7 & 2.64 \\
\hline 8 & 422.3 & 70.9 & 1.98 & 31 & 425.8 & 11.7 & 2.64 \\
\hline 9 & 491.1 & 70.9 & 1.98 & 32 & 314.8 & 3.42 & 2.64 \\
\hline 10 & 303.1 & 70.9 & 1.98 & 33 & 376.0 & 3.42 & 2.64 \\
\hline 11 & 298.0 & 1.01 & 3.13 & 34 & 418.6 & 3.42 & 2.64 \\
\hline 12 & 353.0 & 1.01 & 3.13 & 35 & 309.4 & 1.00 & 2.64 \\
\hline 13 & 298.0 & 1.01 & 1.12 & 36 & 734.0 & 1.01 & 0.33 \\
\hline 14 & 353.0 & 1.01 & 1.12 & 37 & 393.0 & 1.01 & 0.33 \\
\hline 15 & 353.0 & 1.01 & 4.25 & 38 & 734.0 & 1.01 & 0.33 \\
\hline 16 & 293.0 & 1.01 & 0.18 & 39 & 393.0 & 1.01 & 0.33 \\
\hline 17 & 307.6 & 1.01 & 4.25 & 40 & 734.0 & 1.01 & 0.33 \\
\hline 18 & 302.6 & 1.01 & 0.09 & 41 & 413.1 & 1.01 & 0.33 \\
\hline 19 & 973.0 & 1.01 & 0.26 & 42 & 399.7 & 1.01 & 0.99 \\
\hline 20 & 563.3 & 1.01 & 0.26 & 43 & 308.0 & 1.01 & 3.76 \\
\hline 21 & 377.6 & 1.01 & 0.26 & 44 & 328.0 & 1.01 & 3.76 \\
\hline 22 & 377.6 & 1.01 & 0.26 & 45 & 363.0 & 1.01 & 2.51 \\
\hline 23 & 377.5 & 1.01 & 0.25 & 46 & 333.0 & 1.01 & 2.51 \\
\hline
\end{tabular}

$\mathrm{BMG}$, in order for the DFE to deliver $300 \mathrm{~kW}_{\mathrm{e}}$ in the dual fuel mode.

The total electricity produced is $2.18 \mathrm{MW}$ h per year with the DFE contributing about $25.76 \%$, and the A-CAES system about $74.24 \%$. It is interesting to observe that about $86 \%$ of the excess wind electricity used during the charging mode is produced in the A-CAES during the discharging mode. This characteristic demonstrates the hybrid nature of the A-CAES + BMGES system and it is so because of the added syngas and exhaust heat energy which is used to further heat up the air to a higher temperature after compression in the compressor and during expansion mode respectively. The total heat recovered from the system for district heating is about $586.37 \mathrm{MW} \mathrm{h}_{\text {th }}$ per year representing only about $0.16 \%$ of the total input fuel energy. This recovered heat, is $100 \%$ from the DFE cooling system jacket water.

Although about 60 to $70 \%$ of the energy input of the fuel in the DFE is contained in the thermal energy contained in the exhaust gas and cooling systems, ${ }^{52}$ the total percentage of the recovered heat is low because part of the heat content of the exhaust gas is used to heat up the air after the TEST before expansion in the AE stages. The system electrical efficiency is about $28.97 \%$; the total system efficiency for the production of heat and power is about $36.81 \%$. Table 7 shows the technical performance of the overall integrated A-CAES + BMGES system. The thermal storage capacity of the thermal energy storage tanks, $\mathrm{TES}_{1}, \mathrm{TES}_{2}$ and $\mathrm{TES}_{3}$ is estimated as $0.19,0.16$ and 0.36 MW respectively. As can be observed, the thermal capacity of $\mathrm{TES}_{3}$ is about double that of $\mathrm{TES}_{1}$ and $\mathrm{TES}_{2}$. This can be explained by higher temperature difference in $\mathrm{TEST}_{3}$ made possible by highest and lowest temperature of HTF entering the
Table 7 Technical performance results for the integrated system

\begin{tabular}{|c|c|}
\hline Parameter, symbol (unit) & Case \\
\hline Air compressor power input, $P_{\mathrm{AC}}(\mathrm{MW})$ & 0.99 \\
\hline \multicolumn{2}{|c|}{ Thermal storage capacity of TEST, $Q_{\mathrm{Th}, \mathrm{TEST}}\left(\mathrm{MJ} \mathrm{s}^{-1}\right)$ : } \\
\hline $\mathrm{TES}_{1}$ & 0.19 \\
\hline $\mathrm{TES}_{2}$ & 0.16 \\
\hline $\mathrm{TES}_{3}$ & 0.36 \\
\hline Total electricity output, $P_{\mathrm{T}}\left(\mathrm{MW}_{\mathrm{e}}\right)$ & 1.16 \\
\hline System electrical efficiency, SEE (\%) & 29.0 \\
\hline Total system efficiency, TSE (\%) & 36.8 \\
\hline Air storage (AS) size, $V_{\mathrm{AS}}\left(\mathrm{m}^{3}\right)$ & 1549 \\
\hline
\end{tabular}

Heat recovery:

Heat recovered from compressed air, $\mathrm{RH}_{\mathrm{AC}}\left(\mathrm{MW}_{\mathrm{th}}\right)$

Heat recovered from syngas, $\mathrm{RH}_{\mathrm{sg}}\left(\mathrm{MW}_{\mathrm{th}}\right) \quad 0.06$

Total heat recovered during charging, $\mathrm{RH}_{\mathrm{t}, \mathrm{ch}}\left(\mathrm{MW}_{\mathrm{th}}\right) \quad 0.24$

Total heat recovered discharging, $\mathrm{RH}_{\mathrm{t}, \mathrm{dch}}\left(\mathrm{MW}_{\mathrm{th}}\right)$

Heat required by dryer, $\left(\mathrm{kW}_{\mathrm{th}}\right) \quad 0.20$

Area of heat exchangers:

$A_{\mathrm{HXAC} 1}\left(\mathrm{~m}^{2}\right) \quad 147.4$

$A_{\mathrm{HX} \_ \text {AC4 } 4}\left(\mathrm{~m}^{2}\right) \quad 3.29$

$A_{\mathrm{HXBMG}, \mathrm{sg}}\left(\mathrm{m}^{2}\right) \quad 0.91$

$A_{\mathrm{HXAE} 1}\left(\mathrm{~m}^{2}\right) \quad 8.50$

$A_{\mathrm{HXAE} 2}\left(\mathrm{~m}^{2}\right) \quad 8.72$

$A_{\mathrm{HXAE3}}\left(\mathrm{m}^{2}\right) \quad 7.38$

$A_{\mathrm{HX}, \mathrm{DFE}, \mathrm{ex}}\left(\mathrm{m}^{2}\right) \quad 0$

$A_{\mathrm{HX}, \mathrm{DFE}, \mathrm{cw}}\left(\mathrm{m}^{2}\right) \quad 47.11$

TEST during the charging and discharging modes respectively when compared with TEST $_{1}$ and TEST $_{2}$.

The analysed A-CAES + BMGES system is not a single ES technology but a hybrid ES system. Thus comparing its efficiency with an A-CAES system can be misleading. However, the efficiency values computed (both SEE and TSE) assume fairly moderate values when compared with data found in the technical literature for both A-CAES and similar hybrid systems. As a matter of fact, Garrison and $W^{-b b e r}{ }^{27}$ reported an overall efficiency of $46 \%$ for a coupled solar-CAES system. Zhao et al. ${ }^{78}$ reported RTE ranging from 70-74 for a hybrid A-CAES and flywheel energy storage system (FESS). In another study, electrical efficiencies ranging from 24.79-62.09 was reported by Karellas and Tzouganatos ${ }^{79}$ for an A-CAES system of different configuration (i.e. different stages with and without air preheating). Liu and Wang ${ }^{24}$ presented RTEs that vary between $53.9 \%$ and $66.98 \%$.

Facci et al. ${ }^{26}$ estimated system electrical efficiencies of $30.2 \%$ for tri-generative compressed air storage (T-CAES) compatible for a small to medium size civil application. It was reported that the efficiency could vary between 20 to $40 \%$ depending on the operating storage pressure (10-100 bar) ${ }^{80}$ In another study Kim and Favrat $^{\mathbf{8 1}}$ presented efficiencies that vary from $23.6 \%$ to $71.6 \%$. The wide variation in the reported efficiencies of CAES emanates from the fact that different configurations, operating parameters and conditions are applied by the various authors in their analysis. Such parameters include (a) the average storage pressure, (b) the compressors and turbines efficiencies, (c) the number of stages of AEs and ACs. Table 8 shows the important 
Table 8 Economic performance results for the integrated system

\begin{tabular}{ll}
\hline Parameter, (unit) & Value \\
\hline TIC, $(£)$ & 2374370 \\
NPV,$(£)$ & -2144062 \\
TLCC, $(\$)$ & 4421655 \\
COE,$(£$ per kW h) & 0.19 \\
Specific investment cost, A-CAES + BMGES $\left(£\right.$ per $\left.\mathrm{kW}_{\mathrm{e}}\right)$ & 2040
\end{tabular}

$\begin{array}{ll}\text { Specific cost, TEST }(£ \text { per } \mathbf{k W} \text { th }): & \\ \mathrm{TES}_{1} & 24.32 \\ \mathrm{TES}_{2} & 25.81 \\ \mathrm{TES}_{3} & 17.53\end{array}$

Shares of components in TIC (\%):

$\begin{array}{ll}c_{\mathrm{AC}} & 15.41 \\ c_{\mathrm{AE}} & 13.45 \\ c_{\mathrm{HAD}} & 0.82 \\ c_{\mathrm{BMG}+\mathrm{DFE},} & 34.96 \\ c_{\mathrm{TES}} & 5.08 \\ c_{\mathrm{HX}} & 4.45 \\ c_{\mathrm{AS}} & 25.82\end{array}$

economic results for the system. In the table, the TIC of the ACAES + BMGES system is estimated as $£ 2374370$ representing a minimum A-CAES + BMGES system specific cost of about $£ 2040$. The estimated COE and TLCC for the system is $0.19 £ \mathrm{~kW}$ per $\mathrm{h}$ and $£ 4.4$ million respectively.

The total CAPEX value for thermal energy storage in the ACAES + BMGES is estimated as $£ 67.65$ per $\mathrm{kW}$ h comprising of $£ 24.31$ per $\mathrm{KW}$ h for TES1, £25.81 per $\mathrm{kW}$ h for TES2 and 17.53 per kW h TES3 respectively. The estimated cost of TES values is within the range of $£ 8.70-43.59$ per $\mathrm{kW} \mathrm{h}(€ 10-50$ per $\mathrm{kW} \mathrm{h})$ reported as costs of latent heat storage systems based on PCMs. ${ }^{82}$ It can be observed that the specific cost of $\mathrm{TES}_{1}$ and $\mathrm{TES}_{2}(£$ per $\mathrm{kW} \mathrm{h}$ ) are more than that of $\mathrm{TES}_{3}$ by over $40 \%$. This is because, more heat is stored in TEST $_{3}$ owing to higher HTF temperature entering it when compared with TEST1 and TEST ${ }_{2}$. In addition, the cold PCM temperature in TEST $_{2}$ is higher than in TEST $_{3}$ since the temperature of the compressed air from the air store entering TEST $_{3}$ is at ambient. In TEST 1 and TEST 2 , the cold temperature of the PCMs is set by the minimum TET from the AEs which is higher than ambient temperature. It is fascinating to assess the shares of cost of the different components of the A-CAES + BMGES system in the TIC as in Table 8. The CAES has the highest share of all the components of the system. It accounted for about $59.8 \%$ of the TIC consisting of $15.4 \%$ for AC, $13.5 \%$ for $\mathrm{AE}, 5.1 \%$ for TES and $25.8 \%$ for AS. The biomass gasifier with cleaning system and the DFE has the second highest share of $35 \%$ with the syngas cleaning system contributing $6.3 \%$. The recuperator accounted for $4.45 \%$. The NPV for the system is found to be negative with a value of $£ 2144062$ indicating the nonprofitability of the system in the selected location.

\subsection{Sensitivity analyses}

4.1.1 Impact of cost factors. The performance of the integrated system depends on a number of technical and cost factors. Cost factors include the total investment cost (TIC), the discount rate $(d)$, the fuel price, the O\&M cost $\left(c_{\mathrm{O} \& \mathrm{M}}\right)$, inflation rate $(e)$, and cost of excess electricity (sold and bought). The technical factors are the syngas fraction (sf), capacity factor (CF), round trip efficiency (RTE) of the A-CAES TES system, the syngas temperature (SGT) and the exhaust gas temperature (EGT) of the DFE. In the sensitivity analyses, the effect of changes in the technical and economic parameters were studied and analysed so as to evaluate their effects on the overall specifications of the system. Specifically, in the cost sensitivity, the base line value of each cost parameter input into the COE calculation is adjusted by multiplying each of the base line cost parameters by a base line cost component multiplier (BCCM) that ranged from a smallest value of 0.3 to highest value of 1.5 in accordance with IEA methodology for energy plants. ${ }^{4}$ Then a sensitivity plot (SP) of COE for the variation of the factors is illustrated. The greater the slope of the COE is with respect to the relative change in the cost factor, the bigger the influence on the COE and vice versa. Fig. 5 shows the results of this sensitivity analysis for the COE. As it can be observed, the TIC has the steepest slope of the factors and thus has the strongest influence on the COE. This is because TIC remain the single biggest element of the system's cost. If the TIC increases from its base line value by a BCCM of 1.3 (30\% increase) while all other variables are held constant, the $\mathrm{COE}$ increases to $0.23 £$ per $\mathrm{kW}$ h. This represents a percentage increase in the COE of about $19.5 \%$. However, at a BCCM of 0.7 (30\% reduction), the COE reduces by about $19.5 \%$ to $15.25 \mathrm{p}$ per $\mathrm{kW}$ h which is outside the range of current UK national average price for electricity which is $14.05 \mathrm{p}$ per $\mathrm{kW} \mathrm{h.}{ }^{74}$ This fairly high percentage change in COE with variation in the TIC highlights the significant sensitivity of the COE to change in the TIC.

The discount rate $(d)$ has the second highest impact on COE. The COE is found to increase with increasing discount rate. This is because the discount rate influences the costs of capital. The higher the discount rate, the higher the cost of capital and vice versa. The COE for the discount rate varied from a low value of about $0.14 £$ per $\mathrm{kW}$ h at a low BCCM of $0.3(d=3 \%)$ to a high value of about $0.23 £$ per $\mathrm{kW}$ h at a BCCM of $1.5(d=15 \%)$, representing about $21.7 \%$ increase in COE from the base value.

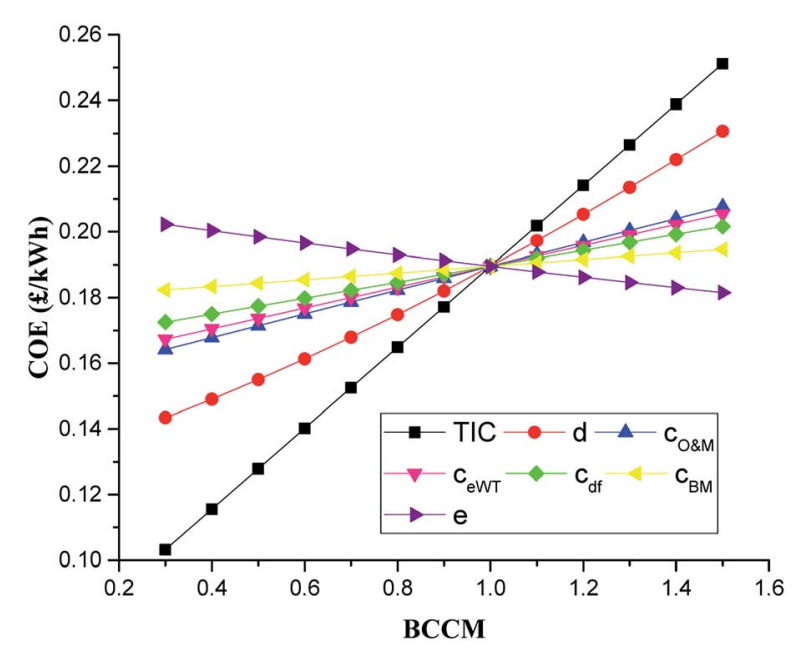

Fig. 5 Impact of economic factors on COE. 
The other parameters do not influence the COE significantly compared to the TIC and discount rate. Cost of O\&M $\left(c_{\mathrm{O} \& \mathrm{M}}\right)$ and excess wind electricity $\left(c_{\text {eWT }}\right)$ has third and fourth highest impact on the COE with COE increasing by about $9.5 \%$ and $8.4 \%$ in each over BCCM range of 1 (base value) to 1.5 respectively.

The COE is least sensitive to the cost of biomass $\left(c_{\mathrm{BM}}\right)$, which sees only about $2.7 \%$ increase in COE as the BCCM is increased from base value to 1.5. The inflation rate $(e)$ has the second least impact on the COE followed by the cost of diesel $\left(c_{\mathrm{df}}\right)$. As can be observed the inflation rate $(e)$ is inversely correlated to the COE, with higher $e$ values resulting in lower COEs and vice versa. The COE increases by about $6.4 \%$ within the same BCCM range of 1 to 1.5 for cost of diesel fuel $\left(c_{\mathrm{df}}\right)$.

The corresponding TLCC for the system under the factors accessed in the COE sensitivity above is shown in Fig. 6. The sensitivity of the factors to the TLCC also followed the same order as that in the COE with TIC impacting TLCC the highest and cost of biomass the least. One would have expected the cost of biomass to impact the system COE more since it is one of the fuel used by the system. However, because the system takes advantage of cheap waste heat to dry cheap wet biomass, the cost of biomass seemingly does not impact on the COE significantly. Along similar lines, the influence of changing the cost factors (TIC, $c_{\mathrm{BM}}, c_{\mathrm{eWT}}, c_{\mathrm{df}}, c_{\mathrm{O} \& \mathrm{M}}, c_{\mathrm{BM}}$ ) including the selling price for heat and electricity ( $\left.e_{\text {tarrif }}, h_{\text {tarrif }}\right)$ on the NPV was analysed. The NPV is important because it is an indicator of how profitable the proposed system would be when implemented. The NPV of the system remained negative as the cost factors were reduced to BCCM of 0.4. This means the A-CAES + BMGES system is not profitable for heat and power generation in the analysed location. However, if $70 \%$ of TIC is provided for by means of a subsidy to the investor by the government as one of the ways to encourage RE uptake in the energy mix, the system become profitable with a positive NPV value of $£ 132474.9$ and COE of $0.10 £$ per $\mathrm{kW} \mathrm{h}$ at the baseline discount rate.

4.1.2 Impact of technical factors. The syngas fraction (sf) of the DFE also plays a part in the overall efficiency and hence cost of the whole system. The sf was varied between $1 \%$ and $80 \%$ as in Fig. 7. As can be seen, the COE is highest at first and as the sf of the dual fuel engine decreases, the diesel fraction (DF) rises to keep the power output constant. The increase in the diesel

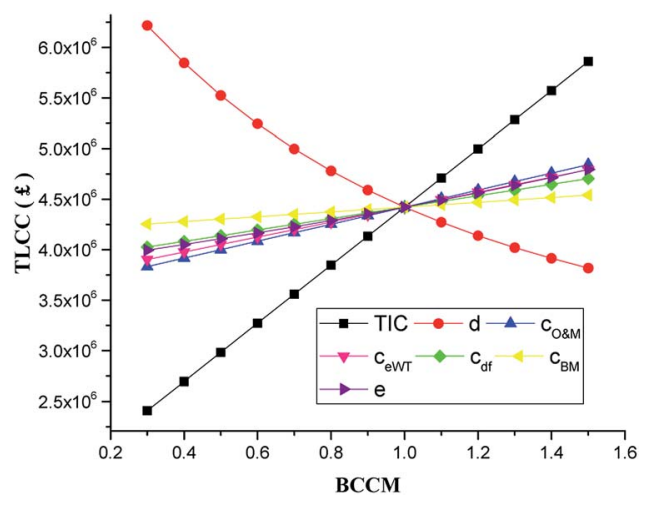

Fig. 6 Impact of economic factors on TLCC.

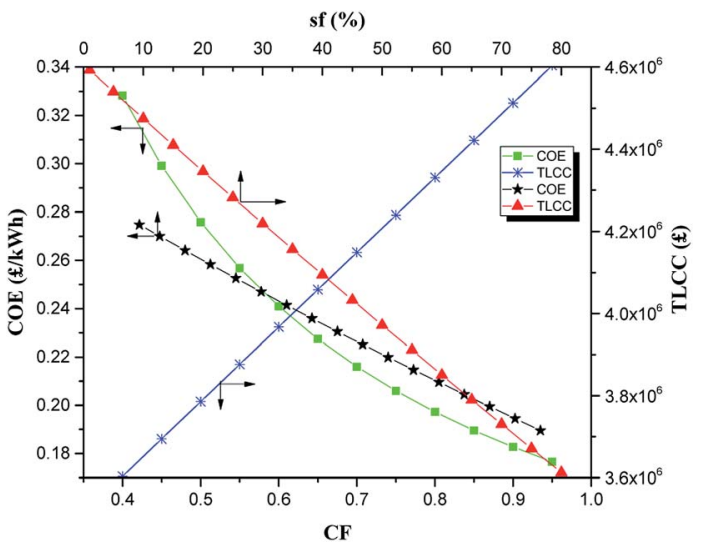

Fig. 7 Impact of variation of sf and CF on COE and TLCC.

fuel consumption leads to a corresponding increase in diesel cost $\left(c_{\mathrm{df}}\right)$. Thus the effect of increase in diesel fuel cost $\left(c_{\mathrm{df}}\right)$ at low sf resulted to a high COE of about $0.27 £$ per $\mathrm{kW} \mathrm{h}$ for the system at sf of $1 \%$. This represents a COE increase of about $45 \%$ from the base value. As can be observed, the relative impact of the change of sf on the COE is significant for the system. The corresponding TLCC for the system is also shown in Fig. 7. Just like the COE, the TLCC is low at first when the sf is highest because of the reduced cost of fuel resulting from less diesel in the fuel mixture. As the sf decreases, the DF consumption and hence the cost of diesel $\left(c_{\mathrm{df}}\right)$ increase with a consequent increase of the TLCC of the system.

The capacity factor (CF) of the integrated system also affects the COE. Just like the sf, the CF is also inversely correlated to COE, with higher CFs resulting in lower COEs and vice versa. This can be seen from Fig. 7. As the CF increases, the number of operating hours of the system increases resulting in the increase in generated energy by the system. On the other hand, as the CF reduces, the yearly operating hours of the system declines resulting in less power generation and increase of the COE of the integrated system. As can be seen in Fig. 7, the CF has a fairly strong effect on the performance of the integrated system. For a CF increase from 0.85 to 0.95 , the COE reduces from 0.1895 to $0.1765 £$ per $\mathrm{kW}$ h representing a decrease of about $7 \%$. On the other hand, for a CF decline from 0.85 to 0.75 , the COE increases by about 9\%. Over the CF range of 0.4-0.95, the COE varied from a highest value of $0.328 £$ per $\mathrm{kW}$ h to the lowest vale of $0.177 £$ per $\mathrm{kW}$ h. The TLCC for the system has a linear relationship with CF because of increase in the number of operating hours and hence cost of O\&M that resulted with increasing $C F$. It varied from a lowest value of about $£ 3.60$ million at CF of 0.4 to the highest value of $£ 4.60$ million at CF of 0.95 .

A less efficient TES system of A-CAES will generate less electricity than a more efficient storage system. The impact of RTE of the TES of the A-CAES on the COE, TSE and $P_{\mathrm{A} \text {-CAES }}$ of the system is shown in Fig. 8 over the range of 40 to $95 \%$. As can be seen, the COE for the system varies inversely with the RTE. This is because, as the RTE of the A-CAES TES increases, the power generated by the A-CAES ( $\left.P_{\mathrm{A} \text {-CAES }}\right)$ and hence the whole system increases as in Fig. 8, leading to the increase in the total system 


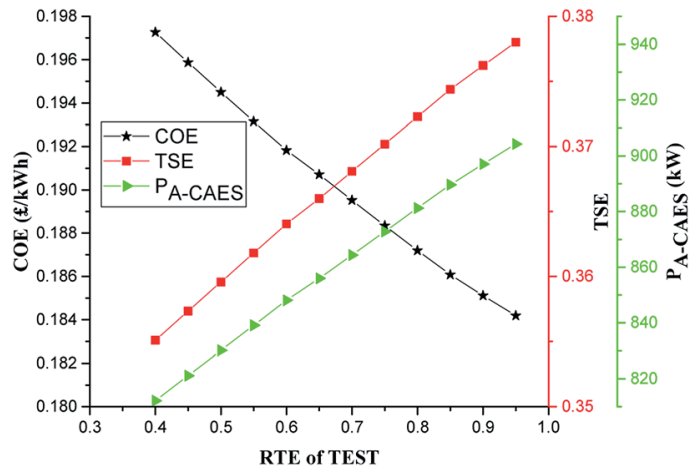

Fig. 8 Impact of RTE of A-CAES TEST on COE.

efficiency (TSE). The increased efficiency and power output of the A-CAES + BMGES at higher RTE thus leads to a reduced COE. A reduction of the RTE from the base value of $70 \%$ to $40 \%$ leads to about $4.1 \%$ increase in the COE to $0.1973 £$ per $\mathrm{kW} \mathrm{h}$ whereas an increase of RTE from the base value to $95 \%$ leads to about $2.8 \%$ reduction in the COE to $0.1842 £$ per $\mathrm{kW}$ h. Over the RTE range of 40 to $95 \%$ the total system efficiency (TSE) increases from 0.355 to 0.38 .

Fig. 9 shows the EGT sensitivity to the COE of the A-CAES + BMGES system. The most immediate and direct impact of EGT on the system is the variation of the TIT and hence TSE. In dual fuel mode, the EGT is usually higher than the diesel only mode at the same load. ${ }^{83}$ This may be due to slow combustion flame speed resulting from the incomplete combustion features of the syngas which leads to a fairly higher exergy loss through exhaust gas. The typical EGT of dual fuel compression ignition (CI) engine operating on diesel fuel and refined rice bran oil blends, having a compression ratio of $18.4: 1$ can vary from a low value of $341{ }^{\circ} \mathrm{C}$ at $63 \%$ load and $50 \%$ sf to a high value of $524{ }^{\circ} \mathrm{C}$ at $98 \%$ load and $75 \%$ sf, depending on the load, DF, compression ratio and ambient conditions. ${ }^{84}$

Based on $120{ }^{\circ} \mathrm{C}$ as the final stack temperature, varying the starting temperature of the DFE exhaust gas temperature from $361{ }^{\circ} \mathrm{C}(634 \mathrm{~K})$ up to $541^{\circ} \mathrm{C}(814 \mathrm{~K})$ results in about $75 \%$ increase in temperature difference available and thus, available energy for recovery. The degree to which the energy obtainable in the higher EGT can be utilised depends on the characteristics of the system. Within the EGT range of studied, it is observed that increase in EGT improved the performance of the system. The

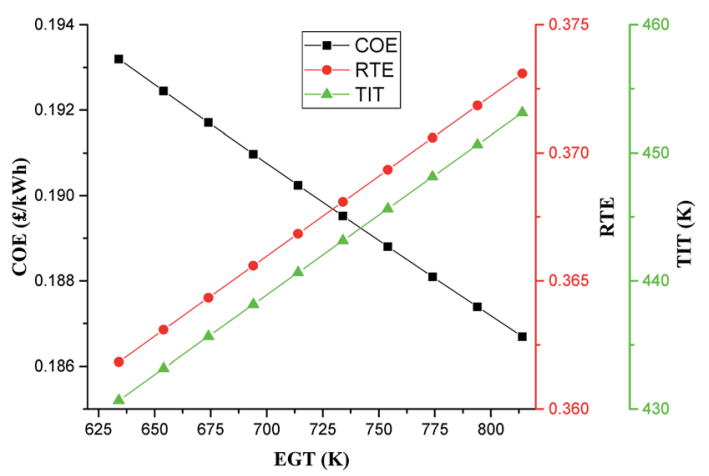

Fig. 9 Impact of EGT on COE.

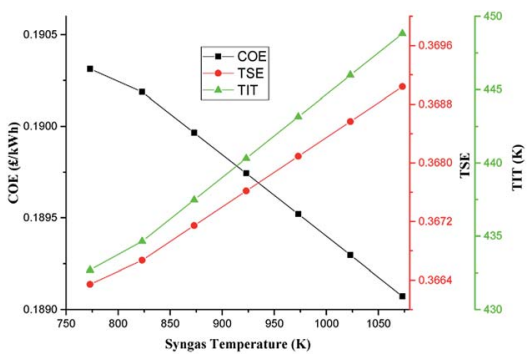

Fig. 10 Impact of syngas temperature on COE.

TSE increased from 36.2 to $37.3 \%$. The increase in the TSE is due to increase in available heat for recovery at high EGT which leads to increase in TIT as can be seen in Fig. 8. As expected the increase in the overall performance of the system at higher EGT led to improved COE of the system.

Fig. 10 shows the sensitivity of COE of the system on the temperature of syngas (SGT) exiting the gasifier during the charging mode. As expected, the COE of the system varies inversely with the SGT. As the SGT reduces from the base case value of $973 \mathrm{~K}$ to $773 \mathrm{~K}$, the COE increased from 0.1895 to 0.1903 $£$ per $\mathrm{kW}$ h. However, as the SGT is increased from the base value to $1073 \mathrm{~K}$, the COE reduced to $0.1891 £$ per $\mathrm{kW}$ h. The trend can be explained by the increase in the TSE with SGT. With increase in SGT from the base value to $1073 \mathrm{~K}$, the higher TSE reveals the benefit of reheating on efficiency. TES efficiency rises with air re-heating since the increased turbine inlet temperature (TIT) in the $\mathrm{AE}$ stages leads to increased power outputs and hence TSE as can be seen in Fig. 9 .

Fig. 11 shows the percentage variation of the NPV of the system to the variation of the sensitivity factors examined above from their minimum and maximum values. It can be seen clearly that the most significant factors swaying the NPV of the A-CAES + BMGES are TIC, cost of O\&M, excess wind electricity cost, electricity tariff, and cost of diesel fuel

\subsection{Limitations of the study}

The result of the study should not be considered as representative of the UK or the world in any way. Electricity and heat

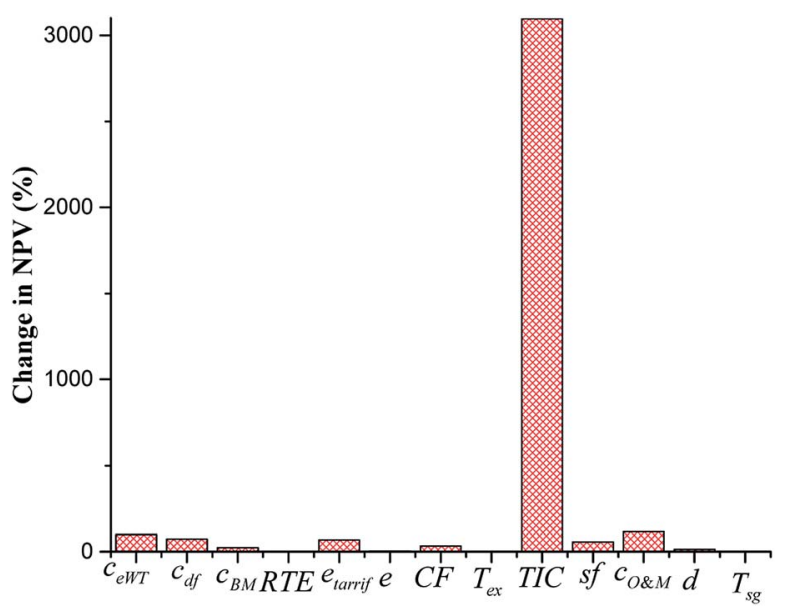

Fig. 11 Variation of NPV with sensitivity cost parameters. 
demand including energy prices depends on a range of different supply and demand situations, including the geopolitical location, local climate, the national energy mix, network costs and taxation. Hence, the case study using Hull should only be considered as an example of the applicability of the methodology. The methodology can be scaled up to any capacity and used for any location or country while factoring in labour costs, fuels and electricity prices. Moreover, it should be noted the details of the hybrid systems cost and economics are valid elsewhere. The primary differences between the systems would be ensuring they meet the standards of the local regulators in the region of interest.

\section{Conclusions and recommendations}

A wind powered A-CAES system and a downdraft biomass gasifier with dryer coupled to a dual fuel engine are integrated in this paper to produce heating and power simultaneously for supplying some of the energy needs of 1600 households in Hull humber region.

Techno-economic analysis is carried out to investigate the performance of the system. The technical assessment focused mainly on electrical power generation, fuel consumption and efficiencies. The economic analysis is carried out based on total life cycle cost (TLCC), cost of electricity (COE), and net present value (NPV). Moreover a sensitivity analysis is carried out to appraise the effects of important technical and cost parameters on system performance. The main conclusions are summarized as follows:

- The results obtained indicates that the proposed system is technically possible for commercial distributed power and heat generation. It uses renewable energy and can simultaneously produce electrical and heating energy.

- Within the baseline design conditions, the system has the capability to produce a total electric power output of $1.16 \mathrm{MW}$ (869.51 kW from A-CAES and 0.3 from DFE), $0.315 \mathrm{~kW}$ heat for sale and $318.03 \mathrm{~kg}$ of dry wood chips per hour with electric efficiency of about $29 \%$ and total system efficiency for the simultaneous production of heat and electricity of $36.8 \%$. To achieve this, the system requires wind turbine excess electricity of $1 \mathrm{MW}$, a biomass gasifier with capacity to process $318.03 \mathrm{~kg}$ of wood per hour and a 0.3 MWe dual fuel engine with syngas and diesel consumption of 23.74 and $881.77 \mathrm{~kg} \mathrm{~h}^{-1}$ respectively.

- Results of economic analysis shows that the COE of the system $(0.19 £ \mathrm{~kW} \mathrm{~h})$ is outside the range of the average cost of electricity for a medium user home in the UK (2500 to 5000 $\mathrm{kW}$ h a year), including taxes which is $15.2 \mathrm{p}$ per $\mathrm{kW} \mathrm{h}$.

- Results of the sensitivity analysis of the technical parameters showed that increasing the EGT, RTE of A-CAES TEST and SGT increases the TSE of the system. In addition, it is concluded that since the A-CAES is interconnected with BMG and DFE, any variation in the parameter of BMG or DFE, will cause a variation in the performance of the A-CAES + BMGES system.

- The economic results of the system and the sensitivity (Fig. 5-10) provide investors with clear guides to the COE of the hybrid systems for distributed generation. The negative NPV of the system even with modest TIC reduction coupled with high COE cost as compared to global average COE of about $0.1 \$$ per $\mathrm{kW} \mathrm{h}$ shows that the integrated system is not economically viable for distributed electricity generation in the selected location unless about $70 \%$ the TIC of the system is met by a government subsidy.

The economic position of the system may be further enhanced in the future by:

- Reducing CAES and BMG plant cost, which can occur through efficiency improvements as well as commercialisation.

- Increasing sell back to the grid tarrifs for power exported by private commercial generators.

- Granting high subsidy to investment in hybrid biomass and wind generation systems.

- Possible reductions in O\&M, fuel, and other BOP costs have a moderately small effect, but of course should not be ignored as part of overall cost reductions.

It should be taken note of, that these results are independent of renewable energy certificates, feed-in tariffs or other government subsidies. The expected reduction in A-CAES and BMG costs due to commercialisation, standardisation, lower cost of capital and technology learning in the future is likely to improve the economy of the overall system.

\section{Conflicts of interest}

The authors declare no conflict of interest.

\section{Nomenclature}

\begin{tabular}{|c|c|}
\hline $\mathrm{AC}$ & Air compressor \\
\hline $\mathrm{AE}$ & Air expander \\
\hline AS & Air store \\
\hline BMG & Biomass gasifier/gasification \\
\hline BOP & Balance of plant \\
\hline BY & Base year or current year \\
\hline $\mathrm{C}$ & Cost $(\$)$ \\
\hline $\mathrm{Cc}$ & Counter current \\
\hline$c_{\mathrm{r}, \mathrm{e}}$ & Rejected wind electricity cost \\
\hline$c_{\text {ect }}$ & Electricity consumer tariff ( $\$$ per $\mathrm{kW} \mathrm{h}$ ) \\
\hline$c_{\text {est }}$ & Electricity sell to grid tariff ( $\$$ per $\mathrm{kW} h$ ) \\
\hline$c_{\text {ebt }}$ & Electricity buy back tariff ( $\$$ per $\mathrm{kW} \mathrm{h}$ ) \\
\hline$c_{\text {het }}$ & Heat consumer tariff ( $\$$ per $\mathrm{kW} \mathrm{h})$ \\
\hline$c_{\mathrm{hst}}$ & Heat sell back tariff ( $\$$ per $\mathrm{kW} \mathrm{h})$ \\
\hline$c_{\mathrm{hbt}}$ & Heat buy back tariff ( $\$$ per $\mathrm{kW} \mathrm{h})$ \\
\hline$c_{\mathrm{PCM}}$ & PCM cost \\
\hline$c_{\text {steel }}$ & Steel cost $(\$$ per $\mathrm{kg})$ \\
\hline$c_{\text {ins }}$ & Insulation cost $\left(\$\right.$ per $\left.\mathrm{m}^{2}\right)$ \\
\hline $\mathrm{cf}_{\$-£}$ & Conversion factor of $\$$ to $£$ \\
\hline $\mathrm{cf}_{\$-£}$ & Conversion factor of euro to $£$ \\
\hline CGE & Cold gas efficiency \\
\hline$C_{\mathrm{p}}$ & Specific heat capacity $\left(\mathrm{kJ} \mathrm{kg}^{-1} \mathrm{~K}^{-1}\right)$ \\
\hline $\mathrm{CV}$ & Calorific value $\left(\mathrm{kJ} \mathrm{kg}^{-1}\right)$ \\
\hline $\mathrm{CY}$ & Currency year \\
\hline$d$ & Discount factor (real) \\
\hline$D$ & Annual Depreciation (\$) \\
\hline
\end{tabular}




\begin{tabular}{|c|c|}
\hline de & Deficit/imported electricity $(\mathrm{kW})$ \\
\hline$E$ & Power input $(\mathrm{kW})$ \\
\hline$h$ & Enthalpy $\left(\mathrm{J} \mathrm{kg}^{-1}\right)$ \\
\hline $\mathrm{HX}$ & Heat exchanger \\
\hline $\mathrm{HV}$ & Syngas heating value $\left(\mathrm{MJ} \mathrm{m}^{-3}\right)$ \\
\hline hrs & Hours of operation in a year (hrs) \\
\hline$L_{\mathrm{m}}$ & Specific melting enthalpy $\left(\mathrm{J} \mathrm{kg}^{-1}\right)$ \\
\hline$\dot{m}_{\mathrm{a}, \mathrm{D}}$ & Mass flow rate of air in dryer $\left(\mathrm{kg} \mathrm{s}^{-1}\right)$ \\
\hline$\dot{m}_{\mathrm{D}, \mathrm{AC}}$ & Mass flow rate of air in $\mathrm{HX} 1\left(\mathrm{~kg} \mathrm{~s}^{-1}\right)$ \\
\hline$\dot{m}_{\mathrm{D}, \mathrm{sg}}$ & Mass flow rate of air in $\mathrm{HX} 3\left(\mathrm{~kg} \mathrm{~s} \mathrm{~s}^{-1}\right)$ \\
\hline$\dot{m}_{\mathrm{BM}, \mathrm{e}}$ & Mass dry feed at exit $\left(\mathrm{kg} \mathrm{s}^{-1}\right)$ \\
\hline$\dot{m}_{\mathrm{BM}, \mathrm{i}}$ & Mass of dry feed at inlet $\left(\mathrm{kg} \mathrm{s}^{-1}\right)$ \\
\hline$\dot{m}_{\mathrm{w}, \mathrm{i}}$ & Mass of water biomass at inlet $\left(\mathrm{kg} \mathrm{s}^{-1}\right)$ \\
\hline$\dot{m}_{\mathrm{w}, \mathrm{e}}$ & Mass of water biomass at exit $\left(\mathrm{kg} \mathrm{s}^{-1}\right)$ \\
\hline$\dot{m}_{\mathrm{w}, \mathrm{eV}}$ & Mass of water evaporated $\left(\mathrm{kg} \mathrm{s}^{-1}\right)$ \\
\hline$n$ & Economic life (yrs) \\
\hline$n_{\mathrm{s}}$ & Number of stages \\
\hline$P$ & Pressure (bar) \\
\hline PV & Present value \\
\hline$\dot{Q}$ & Flow rate $\left(\mathrm{kg} \mathrm{s}^{-1}, \mathrm{l} \mathrm{s}^{-1}\right)$ \\
\hline$Q_{\mathrm{TES}}$ & Thermal storage capacity (W) \\
\hline$R$ & Gas constant $\left(\mathrm{J} \mathrm{kg}^{-1} \mathrm{~K}^{-1}\right)$ \\
\hline$R$ & Revenues (\$) \\
\hline RH & Recovered heat (MJ) \\
\hline$T$ & Temperature ${ }^{\circ} \mathrm{C}$ \\
\hline Tax & Tax rate $(\%)$ \\
\hline TLCC & Total life cycle cost $(\$)$ \\
\hline$\Delta T_{\mathrm{m}}$ & log mean temperature difference $\left({ }^{\circ} \mathrm{C}\right)$ \\
\hline$V$ & Volume $\left(\mathrm{m}^{3}\right)$ \\
\hline$\dot{m}$ & Mass flow rate $\left(\mathrm{kg} \mathrm{s}^{-1}\right)$ \\
\hline MC & Moisture content by wt (\%) \\
\hline$m_{\mathrm{r}}$ & $\dot{m}$ ratio of the $\mathrm{AE}$ to the $\mathrm{AC}$ \\
\hline
\end{tabular}

\section{Greek symbols}

\author{
Humidity of air $\left(\mathrm{kg} \mathrm{kg}^{-1}\right)$ \\ Density $\left(\mathrm{kg} \mathrm{m}^{-3}\right)$ \\ Pressure ratio per compressor stage \\ Ratio of air specific heats \\ Effectiveness/efficiency \\ Specific fan power $\left(\mathrm{kW} \mathrm{m}^{-3} \mathrm{~s}^{-1}\right)$
}

\section{Subscripts}

$\begin{array}{ll}\text { a } & \text { Air } \\ \text { B } & \text { Biomass/wood } \\ \text { BG } & \text { Biomass gasifier } \\ \text { c } & \text { Cold } \\ \text { ch } & \text { Charge/charging } \\ \text { D } & \text { Annual depreciation } \\ \text { d } & \text { Dry } \\ \text { dch } & \text { Discharge/discharging } \\ \text { df } & \text { Diesel fuel } \\ \text { e } & \text { Electrical/electricity } \\ \text { ev } & \text { Evaporation }\end{array}$

$\begin{array}{ll}\text { ex } & \text { Exhaust } \\ \mathrm{e} & \text { Final/leaving } \\ \mathrm{h} & \text { Heat/hot } \\ \mathrm{HA} & \text { Hot air } \\ \mathrm{HX} & \text { Heat exchanger } \\ \mathrm{i} & \text { Initial/entering } \\ \text { isen } & \text { Isentropic } \\ \text { insu } & \text { Insulation } \\ \mathrm{M} & \text { Mechanical } \\ \mathrm{Max} & \text { Maximum } \\ \text { min } & \text { Minimum } \\ n & \text { Year } \\ \mathrm{o} & \text { Out/outlet/overall } \\ \mathrm{O \& M} & \text { Operation and maintenance } \\ \mathrm{r} & \text { Real } \\ \text { recup } & \text { Recuperation } \\ \text { ref } & \text { Reference } \\ \mathrm{RH} & \text { Percentage relative humidity (\%) } \\ \mathrm{s} & \text { Sensible } \\ \mathrm{T} & \text { Total } \\ t & \text { Time (secs) } \\ \text { theo } & \text { Theoretical } \\ \text { vol } & \text { Volumetric } \\ \mathrm{w} & \text { Wet/moisture } \\ \text { wb } & \text { Wet basis } \\ \text { wv } & \text { Water vapour } \\ \text { WT } & \text { Wind turbine }\end{array}$

\section{Acknowledgements}

This project has received funding from the European Union's Horizon 2020 research and innovation programme under the Marie Sklodowski-Curie grant agreement No. 643322(FLEXIPYROCAT). Chidiebere Diyoke acknowledges the sponsorship received from Enugu State University of Science and Technology (ESUT) through Tertiary Education Trust Fund (TET-Fund), Nigeria for his PhD study.

\section{References}

1 BP, BP Energy Outlook, Energy Outlook 2017, 1-103.

2 EIA, International Energy Outlook 2016 with Projections to 2040, U S Energy Information Administration, 2016, DOE/ EIA-0484(2016), pp. 1-290.

$3 \mathrm{H}$. Lund and G. Salgi, The role of compressed air energy storage (CAES) in future sustainable energy systems, Energy Convers. Manage., 2009, 50, 1172-1179.

4 IEA, Projected Costs of Generating Electricity, International Energy Agency (IEA), 2015.

5 EIA, International Energy Outlook 2017, International Energy Outlook 2017.

6 B. E. Layton, A comparison of energy densities of prevalent energy sources in units of joules per cubic meter, Int. J. Green Energy, 2008, 5, 438-455.

7 ERP, The future role for energy storage in the UK, main Report, Energy Research Partnership (ERP) Technology Report, 2011, pp. 1-47. 
8 A. Evans, V. Strezov and T. J. Evans, Assessment of utility energy storage options for increased renewable energy penetration, Renewable Sustainable Energy Rev., 2012, 16, 4141-4147.

9 C. G. Morris and C. J. Cleveland, Handbook of Energy, Elsevier Science, 2013, p. 1.

10 D. Y. C. Leung, G. Caramanna and M. M. Maroto-Valer, An overview of current status of carbon dioxide capture and storage technologies, Renewable Sustainable Energy Rev., 2014, 39, 426-443.

11 C. Diyoke, S. Idogwu and U. C. Ngwaka, An Economic assessment of biomass gasification for rural electrification in Nigeria, International Journal of Renewable Energy Technology Research, 2014, 3(1), 1-17.

12 ETI, Distributed generation, Energy Technologies Institute (ETI), London, UK, 2012.

13 X. Zhang, H. Chen, Y. Xu, W. Li, F. He, H. Guo, et al., Distributed generation with energy storage systems: a case study, Appl. Energy, 2017, 204, 1251-1263.

14 K. Corfee, G. Stevens and S. Goffri, Distributed Generation Resource Assessment for Long-Term Planning Study, 2014.

15 S. M. Indrawati, Energy and Sustainable Development: What's Next?, World Bank International Student Energy Summit, Indonesia, 2015.

16 Z. Yang, Z. Wang, P. Ran, Z. Li and W. Ni, Thermodynamic analysis of a hybrid thermal-compressed air energy storage system for the integration of wind power, Appl. Therm. Eng., 2014, 66, 519-527.

17 M. Aneke and M. Wang, Energy storage technologies and real life applications - A state of the art review, Appl. Energy, 2016, 179, 350-377.

18 M. Budt, D. Wolf, R. Span and J. Yan, A review on compressed air energy storage: basic principles, past milestones and recent developments, Appl. Energy, 2016, 170, 250-268.

19 W. Daniel, Methods for Design and Application of Adiabatic Compressed Air Energy Storage Based on Dynamic Modeling, Doctoral dissertation, Fraunhofer Institute, Germany, 2011, pp. 1-175.

20 Y. M. Kim, S. J. Kim and D. Favrat, Potential and evolution of compressed air energy storage:energy and exergy analyses., Entropy, 2012, 14, 1501-1521.

21 A. H. Alami, K. Aokal, J. Abed and M. Alhemyari, Low pressure, modular compressed air energy storage (CAES) system for wind energy storage applications, Renewable Energy, 2017, 106, 201-211.

22 E. Barbour, D. Mingnard, Y. Ding and Y. Li, Adiabatic Compressed air Energy storage with packed bed thermal energy storage, Appl. Energy, 2015, 155, 804-815.

23 W. F. Pickard, N. J. Hansing and A. Q. Shen, Can large-scale advanced-adiabatic compressed air energy storage be justified economically in an age of sustainable energy?, $J$. Renewable Sustainable Energy, 2009, 1, 033102.

$24 \mathrm{~J}$. Liu and J. Wang, A comparative research of two adiabatic compressed air energy storage systems, Energy Convers. Manage., 2016, 108, 566-578.
25 P. C. Loh, L. Zhang and F. Gao, Compact Integrated Energy Systems for Distributed Generation, IEEE Trans. Ind. Electron., 2013, 60(4), 1492-1502.

26 A. L. Facci, D. Sánchez, E. Jannelli and S. Ubertini, Trigenerative micro compressed air energy storage: concept and thermodynamic assessment, Appl. Energy, 2015, 158, 243-254.

27 J. B. Garrison and M. E. Webber, An integrated energy storage scheme for a dispatchable solar and wind powered energy system, J. Renewable Sustainable Energy, 2011, 3, 043101.

28 A. Singh and P. Baredar, Techno-economic assessment of a solar PV, fuel cell, and biomass gasifier hybrid energy system, Energy Reports, 2016, 2, 254-260.

29 M. Caliano, N. Bianco, G. Graditi and L. Mongibello, Design optimization and sensitivity analysis of a biomass-fired combined cooling, heating and power system with thermal energy storage systems, Energy Convers. Manage., 2017, 149, 631-645.

30 S. Singh, M. Singh and S. C. Kaushik, Feasibility study of an islanded microgrid in rural area consisting of PV, wind, biomass and battery energy storage system, Energy Convers. Manage., 2016, 128, 178-190.

31 T. Srinivas and B. V. Reddy, Hybrid solar-biomass power plant without energy storage, Case Studies in Thermal Engineering, 2014, 2, 75-81.

32 D. F. Dominković, B. Ćosić, Z. Bačelić Medić and N. Duić, A hybrid optimization model of biomass trigeneration system combined with pit thermal energy storage, Energy Convers. Manage., 2015, 104, 90-99.

33 T. B. Reed, A. Das. Handbook of Biomass Downdraft Gasifier Engine Systems, SERI/SP-271-3022 DE88001135, US Department of Energy, Solar Energy Research Institute, 1988, pp. 1-140.

34 Y. Huang, Y. D. Wang, S. Rezvani, D. R. McIlveen-Wright, M. Anderson and N. J. Hewitt, Biomass fuelled trigeneration system in selected buildings, Energy Convers. Manage., 2011, 52, 2448-2454.

35 P. J. Woolcock and R. C. Brown, A review of cleaning technologies for biomass-derived syngas, Biomass Bioenergy, 2013, 52, 54-84.

36 M. Rafati, L. Wang, D. C. Dayton, K. Schimmel, V. Kabadi and A. Shahbazi, Techno-economic analysis of production of Fischer-Tropsch liquids via biomass gasification: The effects of Fischer-Tropsch catalysts and natural gas cofeeding, Energy Convers. Manage., 2017, 133, 153-166.

37 R. Wardle and P. Davison, Initial Load and Generation Profiles from CLNR Monitoring Trials, SDRC Report, 2012, DEI-CLNR-DC.

38 DECC, Chapter 3: Domestic energy consumption in the UK between 1970 and 2014, Department of Energy \& Climate Change, 2015, URN: 15D/377, pp. 1-17.

39 S. R. Wood and P. N. Rowley, A techno-economic analysis of small-scale, biomass-fuelled combined heat and power for community housing, Biomass Bioenergy, 2011, 35, 38493858 . 
40 E. Yao, H. Wang, L. Wang, G. Xi and F. Maréchal, Thermoeconomic optimization of a combined cooling, heating and power system based on small-scale compressed air energy storage, Energy Convers. Manage., 2016, 118, 377-386.

41 H. T. Luk, T. Y. G. Lam, A. O. Oyedun, T. Gebreegziabher and C. W. Hui, Drying of biomass for power generation: A case study on power generation from empty fruit bunch, Energy, 2013, 63, 205-215.

42 J. H. Harker, J. R. Backhurst and J. F. Richardson, Coulson and Richardson's Chemical Engineering Volume 2, Butterworth-Heinemann, 5th edn, 2013.

43 T. Gebreegziabher, A. O. Oyedun and C. W. Hui, Optimum biomass drying for combustion - A modeling approach, Energy, 2013, 53, 67-73.

44 L. J. Nilsson, Air-handling energy efficiency and design practices, Energy and Buildings, 1995, 22, 1-13.

45 Clarke Power Generation Inc, Diesel Engine generator set; Model specifications, 2013.

46 S. Dasappa and H. V. Sridhar, Performance of a diesel engine in a dual fuel mode using producer gas for electricity power generation, International Journal of Sustainable Energy, 2013, 32(3), 153-168.

47 S. De, S. Bandyopadhyay, M. Assadi and D. A. Mukherjee, Sustainable Energy Technology and Policies: A Transformational Journey, Volume 2, Green Energy and Technology, 2018, 1, 417.

48 GSTC, Gasifiers for Biomass, Global Syngas Technologies Council 2018, 2018.

49 P. Raman and N. K. Ram, Design improvements and performance testing of a biomass gasifier based electric power generation system, Biomass Bioenergy, 2013, 56, 555571.

50 Z. Gong and A. S. Mujumdar, Finite-element analysis of cyclic heat transfer in a shell-and-tube latent heat energy storage exchanger, Appl. Therm. Eng., 1997, 17, 583-591.

51 Sattler J., Hoffschmidt B., Günther M., Joemann M., Advanced CSP Teaching Materials: Chapter 9, Thermal Energy Storage.

52 L. Goldstein, B. Hedman, D. Knowles, S. I. Freedman, R. Woods and T. Schweizer, Gas-Fired Distributed Energy Resource Technology Characterizations, NREL Report, 2002, NREL/TP-620-34783.

53 A. Mohammadi, M. H. Ahmadi, M. Bidi, F. Joda, A. Valero and S. Uson, Exergy analysis of a combined cooling, heating and power system integrated with wind turbine and compressed air energy storage system, Energy Convers. Manage., 2017, 131, 69-78.

54 J. Pereira da Cunha and P. Eames, Thermal energy storage for low and medium temperature applications using phase change materials - a review, Appl. Energy, 2016, 177, 227238.

55 Danish Energy Agency, Guidelines for Low-Temperature District Heating-A deliverable in the project financially supported by the Danish Energy Agency in the R\&D programme EUDP (Energiteknologisk Udviklings- og Demonstration Program): "EUDP 2010-II: Full-Scale Demonstration of Low-Temperature District Heating in
Existing Buildings", (Energiteknologisk Udviklings- og Demonstrations Program), EUDP, 2014, 64010-0479:1-43.

56 O. Paulsen, J. Fan, S. Furbo and J. E. Thorsen, Consumer Unit for Low Energy District Heating Net, The 11th International Symposium on District Heating and Cooling, 2008.

57 J. J. Lee, D. W. Kang and T. S. Kim, Development of a gas turbine performance analysis program and its application, Energy, 2011, 36, 5274-5285.

58 F. Baldi and C. Gabrielii, A feasibility analysis of waste heat recovery systems for marine applications, Energy, 2015, 80, 654-665.

59 S. Sanaye, M. A. Meybodi and S. Shokrollahi, Selecting the prime movers and nominal powers in combined heat and power systems, Appl. Therm. Eng., 2008, 28, 1177-1188.

60 Y. A. Cengel, Heat Transfer: A Practical Approach, 2nd edn, 2002.

61 G. F. Hewitt and S. J. Pugh, Approximate Design and Costing Methods for Heat Exchangers, Heat Transfer Eng., 2007, 28(2), 76-86.

62 P. Zhao, Y. Dai and J. Wang, Performance assessment and optimization of a combined heat and power system based on compressed air energy storage system and humid air turbine cycle, Energy Convers. Manage., 2015, 103, 562-572.

63 P. Zhao, L. Gao, J. Wang and Y. Dai, Energy efficiency analysis and off-design analysis of two different discharge modes for compressed air energy storage system using axial turbines, Renewable Energy, 2016, 85, 1164-1177.

64 F. Kreith and B. Raton, The CRC Handbook of Thermal Engineering, CRC Press LLC, 2000.

65 G. Towler and R. Sinnott, Chapter 7-Capital Cost Estimating, 2013, pp. 307-54.

66 D. Zafirakis and J. K. Kaldellis, Economic evaluation of the dual mode CAES solution for increased wind energy contribution in autonomous island networks, Energy Policy, 2009, 37, 1958-1969.

67 K. Nithyanandam and R. Pitchumani, Cost and performance analysis of concentrating solar power systems with integrated latent thermal energy storage, Energy, 2014, 64, 793-810.

68 B. Kelly and D. Kearney, Thermal Storage Commercial Plant Design Study for a 2-Tank Indirect Molten Salt System: Final Report, 2006, NREL/SR-550-40166:1-22.

69 IEA, Biomass for Power Generation and CHP, IEA Energy Technology Essentials, 2007, ETE03.

70 BEIS, Evidence Gathering: Thermal Energy Storage (TES) Technologies, Department for Business, Energy and Industrial Strategy, 2016.

71 W. Short, D. J. Packey and T. Holt, A Manual for the Economic Evaluation of Energy Efficiency and Renewable Energy Technologies, National Renewable Energy Laboratory (NREL), 1995.

72 V. Francescato, E. Antonini and L. Z. Bergomi, Wood Fuels Handbook, AIEL-Interlian Agroforestry Association, Italy, 2009.

73 Ofgem, Electricity prices: Day-ahead baseload contracts monthly average (GB), Electricity - wholesale markets 2017. 
74 The Eco Experts, Cost of Electricity per $k W h, 2017$.

75 Business Electricity Prices, A Guide to Wholesale Electricity Pricing, 2017, https:/www.businesselectricityprices.org.uk/ retail-versus-wholesale-prices/.

76 E4tech, Biomass prices in the heat and electricity sectors in the UK, Department of Energy and Climate Change, 2010, URN 10D/546, pp. 1-33.

77 DECC, Assessment of the Costs, Performance, and Characteristics of Heat UK Networks, Department of Energy and Climate Change (DECC), 2015, URN 15D/022, pp. 1-43.

78 P. Zhao, Y. Dai and J. Wang, Design and thermodynamic analysis of a hybrid energy storage system based on ACAES (adiabatic compressed air energy storage) and FESS (flywheel energy storage system) for wind power application, Energy, 2014, 70, 674-684.

79 S. Karellas and N. Tzouganatos, Comparison of the performance of compressed-air and hydrogen energy storage systems: Karpathos island case study, Renewable Sustainable Energy Rev., 2014, 29, 865-882.
80 M. Minutillo, A. Lubrano Lavadera and E. Jannelli, Assessment of design and operating parameters for a small compressed air energy storage system integrated with a stand-alone renewable power plant, Journal of Energy Storage, 2015, 4, 135-144.

81 Y. M. Kim and D. Favrat, Energy and exergy analysis of a micro-compressed air energy storage and air cycle heating and cooling system, Energy, 2010, 35, 213-220.

82 IRENA. Thermal Energy Storage: Technology Brief, IEAETSAP and IRENA Technology Brief E17, 2013.

83 P. Sombatwong, P. Thaiyasuit and K. Pianthong, Effect of Pilot Fuel Quantity on the Performance and Emission of a Dual Producer Gas-Diesel Engine, Energy Procedia, 2013, 34, 218-227.

84 R. N. Singh, S. P. Singh and B. S. Pathak, Investigations on operation of CI engine using producer gas and rice bran oil in mixed fuel mode, Renewable Energy, 2007, 32, 15651580. 